\title{
NOTAS SOBRE LA PENETRACIÓN DEL DERECHO COMÚN EN GALICIA (SIGLOS XII-XV)*
}

\author{
Por \\ FAUSTINO MARTÍNEZ MARTÍNEZ
}

\section{RESUMEN}

El presente trabajo se enmarca dentro de una reflexión general sobre el fenómeno, común a otros territorios de la Península Ibérica, de la llamada recepción del Derecho Común, centrado por razones obvias en Galicia. Nuestra región no fue una excepción a este proceso que se desarrolla con plenitud a partir de los siglos XII y XIII. A través de las páginas de esta colaboración se estudian las condiciones que favorecieron la llegada de las primeras manifestaciones de esta nueva concepción del Derecho (la llamada propiamente «penetración») que sentará las bases para una posterior «recepción».

Estudiamos la progresiva asimilación del derecho común mediante el examen de diferentes documentos que muestran la práctica jurídica (testamentos, contratos, sentencias, etc.).

* Trabajo que ha podido realizarse gracias a una Beca de Investigación de la Excma. Diputación Provincial de A Coruña (Resolución $n^{\circ} 10.672$, de 5 de junio de 2002) y al Proyecto de Investigación «Metodología jurídica: las decisiones judiciales en Galicia» (PGIDIT02 C50 20203 PR) dirigido por el prof. Manuel Segura Ortega (DOGA de $18 \mathrm{de}$ octubre de 2002).

«CUADERNOS DE ESTUDIOS GALLEGOS», Tomo XLVIII, Fascículo 114, Santiago 2001. 


\section{PALABRAS CLAVE}

Historia del Derecho en Galicia, Penetración, Recepción, Derecho Común.

\section{ABSTRACT}

This work on the galician case places in a general thinking about the fenomena, comon to other territories of Iberian Peninsula, of the so-called Common Law reception. Our area was not a exception to this process fully developed from XII and XIII centuries. Across this paper we study the conditions that improve the arrival of this new legal conception (the so-called penetration). The penetration will lay the foundation for the later reception. We study the progressive assimilation of the common law looking into different documents that shows the legal practice (wills, contracts, sentences...).

\section{KEYWORDS}

Roman Law, Canonic Law, Common Law, Reception, History of Galician Law.

\section{1.- INTRODUCCIÓN Y ESTADO DE LA CUESTIÓN. EL DERE- CHO COMÚN: SU EXTENSIÓN POR LA HISPANIA MEDIEVAL}

El fenómeno de la recepción del Derecho Común ha marcado indefectiblemente el devenir evolutivo de los diferentes derechos nacionales o hispánicos como han puesto de relieve estudios particulares ${ }^{1}$ y obras de

\footnotetext{
${ }^{1}$ Como marco general sobre este proceso y del concepto que encierra, vid. LARRAONA, A. y TABERA, A., «El derecho justinianeo en España», en Atti del Congreso Internazionale di Diritto Romano. Istituto di Studi Romani. Tipografia Successori F. Fusi, Pavía, 1935. Tomo II, pp. 83-182; HORN, N., «Literaturgeschichtliche Aspekte
} 
referencia general ${ }^{2}$. Ha sido un fenómeno generalizado y, al mismo tiempo, trascendente. Se ha dicho $-\mathrm{y}$, de alguna manera, esta idea se ha convertido en un axioma admitido por los historiadores del derecho con ca-

der Rezeption in Spanien», en Tijdschrift voor Rechtsgeschiendenis, 37 (1967), pp. 489514; GARCÍA Y GARCÍA, A., «La penetración del derecho clásico medieval en España», en Anuario de Historia del Derecho Español, XXXVI (1966), pp. 575-592; y su volumen En el entorno del Derecho Común. Editorial Dykinson, Madrid, 1999, con varias colaboraciones de interés; FONT-RÍUS, J. M., «El desarrollo general del derecho en los territorios de la Corona de Aragón (Siglos XII-XIV)», en VII Congreso de Historia de la Corona de Aragón. Ponencias. Imprenta Viuda de Fidel Rodríguez Ferrán, Barcelona, 1962, pp. 289-326; y «La Recepción del Derecho Romano en la Península Ibérica durante la Edad Media», en Recueils de Mémoires et Travaux publiés par la Société d'Histoire du Droit et des Institutions des Anciens Pays de Droit Écrit, fascículo VI (1967), pp. 85-104; HINOJOSA Y NAVEROS, E. de, «La recepción y estudio del derecho romano en España», en Obras. Publicaciones del Instituto Nacional de Estudios Jurídicos, Madrid, 1974. Tomo III, pp. 319-358; las colaboraciones de GARCÍA-GALLO, A., BARRERO GARCÍA, A. M. y GONZÁLEZ DÍEZ, G., en el volumen colectivo Diritto Comune e Diritti Locali nella Storia dell'Europa. Atti del Congreso di Varenna. Giuffrè, Milán, 1980, pp. 225-284; PETIT, C., «Derecho Común y Derecho Castellano. Notas de literatura jurídica para su estudio (Siglos XV-XVII)», en Tijdshrift voor Rechtsgeschiendenis, 50 (1982), pp. 157-195; PÉREZ MARTÍN, A. (ed.), España y Europa, un pasado jurídico común. Actas del I Simposio Internacional del Instituto de Derecho Común. Universidad de Murcia, Murcia, 1986; «El estudio de la recepción del Derecho Común», en VV. AA., Seminario de Historia del Derecho y Derecho Privado. Nuevas Técnicas de Investigación. Universidad Autónoma de Barcelona, Bellaterra, 1985, pp. 241-325; y «Derecho Común, Derecho Castellano, Derecho Indiano», en Revista Internazionale di Diritto Comune, 5 (1994), pp. 43-89; SÁNCHEZ-ARCILLA BERNAL, J., «La pervivencia de la tradición jurídica romana en España y la recepción del Derecho Común», en Estudios jurídicos en homenaje al maestro Guillermo Floris Margadant. UNAM, México, 1988, pp. 379-413; IGLESIA FERREIRÓS, A., «La recepción del Derecho Común: estado de la cuestión e hipótesis de trabajo», en El Dret Comú i Catalunya. Actes del II Simposi Internacional. Barcelona, 31 de maig-1 de juny de 1991. Edició d'Aquilino Iglesia Ferreirós. Fundació Noguera. Associació Catalana d'Història del Dret Jaume de Montjuïc, Barcelona, 1992, pp. 213-330; y «Ius Commune: un interrogante y un adiós», en El Dret Comú i Catalunya. Actes del VIII Simposi Internacional. Barcelona,29-30 de maig de 1998. Edició d'Aquilino Iglesia Ferreirós. Fundació Noguera. Associació Catalana d'Història del Dret Jaume de Montjuïc, Barcelona, 1999, pp. 239637; y ClAVERO SALVADOR, B., Temas de Historia del Derecho: Derecho Común. Ediciones de la Universidad de Salamanca, Salamanca, 1994, pp. 40 ss.

${ }^{2}$ Entre los manuales al uso, vid. SÁNCHEZ, G., Curso de Historia del Derecho. Introducción y fuentes. $7^{\mathrm{a}}$ edición corregida. Instituto Editorial Reus, Madrid, 1949, pp. 78 ss.; GIBERT SÁNCHEZ DE LA VEGA, R., Historia General del Derecho español. Imprenta de Francisco Román, Granada, 1968, pp. 41 ss.; y Elementos formativos del Derecho en Europa. Germánico, romano, canónico. Imprenta de Francisco Román, Grà- 
rácter general- que el derecho español (o los derechos españoles), sobre todo en el campo privado, es el resultado de la peculiar evolución del derecho romano en el ambiente hispánico. Con ello no se quiere afirmar, ni mucho menos, que el derecho español o la pluralidad de los derechos hoy llamados especiales o forales, sean sin más la mera transposición del derecho romano en su respectivo ámbito territorial. Hay que distinguir en la afirmación que precede un punto de partida y un punto de llegada que no se pueden identificar en ningún caso. El sustrato del que nace nuestro ordenamiento jurídico hunde sus raíces en Roma. Eso es indiscutible. Pero el ordenamiento que conocemos en la actualidad es el resultado de la participación e influencia de muy diversos factores en el campo social, económico y político, que han marcado el ritmo y el desarrollo de ese derecho romano que se halla en la base de nuestra ciencia jurídica y de nuestro derecho positivo. Finalidad, por tanto, de la Historia del Derecho es mostrar cómo se ha producido esa evolución y cuáles han sido las influencias que jalonan el periplo vital de nuestros ordenamientos jurídicos, desde esa herencia romana, común a otros pueblos mediterráneos, hasta los modernos ordenamientos que nacen al amparo de la codificación. La historicidad del derecho como proceso cultural requiere, pues, el

nada, 1976, pp. 61 ss.; PÉREZ-PRENDES, J. M., Curso de Historia del Derecho español. Volumen I. Universidad Complutense. Servicio de Publicaciones, Madrid, 1989, pp. 637 ss.; GARCÍA-GALlO, A., Manual de Historia del Derecho español. Tomo I. El origen y la evolución del derecho. $8^{\mathrm{a}}$ edición. Artes Gráficas y Ediciones, S.A., Madrid, 1982, pp. 80 ss.; GACTO FERNÁNDEZ, E., ALEJANDRE GARCÍA, J. A. y GARCÍA MARÍN, J. M., El Derecho histórico de los pueblos de España. $3^{\text {a }}$ edición. Servicio de Publicaciones. Facultad de Derecho. Universidad Complutense, Madrid, 1982, pp. 265 ss.; LALINDE ABADÍA, J., Iniciación histórica al Derecho español. $3^{\text {a }}$ edición. Ariel Derecho, Barcelona, 1983, pp. 125 ss.; FERNÁNDEZ ESPINAR, R., Las fuentes del Derecho histórico español. Centro de Estudios Universitarios Ramón Areces, Madrid, 1985, pp. 303 ss.; y Manual de Historia del Derecho español. I. Las fuentes. Centro de Estudios Ramón Areces, Madrid, 1990, pp. 343 ss.; PÉREZ-BUSTAMANTE, R., Historia del Derecho español. Las fuentes del derecho. Editorial Dykinson, Madrid, 1994, pp. 83 ss.; SÁNCHEZ-ARCILLA BERNAL, J., Historia del Derecho. Instituciones politicas y administrativas. Editorial Dykinson, Madrid, 1995, pp. 373 ss.; e Historia del Derecho español. Cálamo Producciones Editoriales, Barcelona, 2001, pp. 171 ss.; IGLESIA FERREIRÓS, A., La creación del derecho. Una historia de la formación de un derecho estatal. $2^{\text {a }}$ edición corregida. Marcial Pons Ediciones Jurídicas y Sociales, Madrid, 1996. Tomo II, pp. 9 ss.; y TOMÁS Y VALIENTE, F., Manual de Historia del Derecho español. $4^{\text {a }}$ edición. Editorial Tecnos, Madrid, 1997, pp. 180 ss. 
estudio en detalle de los factores que inciden de manera determinante en su lenta, pero constante evolución, similar a la que se produce en otros campos de la vida humana.

La llegada del derecho romano, arranque necesario de nuestro periplo, se produce en dos momentos históricos precisos. Tras la conquista e incorporación de la Península al naciente Imperio, Hispania queda convertida en un conjunto de provincias sujetas al mando romano con mayor o menor intensidad lo que determina una permeabilidad diferente al proceso de romanización, entendido como el paulatino camino de asimilación del modo de vida romano ${ }^{3}$. Como resultado de este proceso militar y político, el ordenamiento jurídico del conquistador fue poco a poco aplicándose y extendiéndose por los mecanismos usuales que Roma estilaba hasta concluir con la famosa constitución de Caracalla del año 212 por la que se otorgaba la ciudadanía romana a la totalidad de los habitantes del Imperio. Antes se había ido sucediendo unas primeras tímidas medidas que otorgaron la ciudadanía de manera particularizada a las que siguió la famosa concesión de latinidad en tiempos de Vespasiano. Culminada la romanización jurídica y como consecuencia de la misma, podemos deducir que el derecho romano se aplicó en Hispania, a pesar de la carencia de testimonios materiales y directos al respecto.

Esa extensión personal a todos los habitantes del Imperio de la ciudadanía romana no supuso la aplicabilidad directa del derecho clásico. Tras la constitución de Caracalla, se consolidaría el proceso de vulgarización de la tradición romana. Es decir, nos hallamos ante un territorio en el que se procede a la aplicación del derecho romano, pero sin olvidar el enorme protagonismo que pudieron tener las antiguas prácticas prerromanas de los pueblos ibéricos, la lejanía con respecto a Roma, la falta de publicidad de las principales disposiciones normativas, el desconocimiento generalizado de las obras de los juristas que recogían el derecho antiguo, la propia formación y escasez de las autoridades encargadas de efectuar la aplicación judicial o extrajudicial del derecho, entre otros muchos factores, que han coadyuvado a la formación de ese extraño y ambiguo concepto que se ha

${ }^{3}$ Una exposición clara sobre la romanización jurídica puede consultarse en ALEJANDRE GARCÍA, J. A., Temas de Historia del Derecho: Derecho primitivo y romanización jurídica. Publicaciones de la Universidad de Sevilla, Sevilla, 1977, pp. 39 ss.

«CUADERNOS DE ESTUDIOS GALLEGOS», Tomo XLVIII, Fascículo 114, Santiago 2001. 
denominado, desde Heinrich Brunner, el «derecho romano vulgar», acaso una actitud intelectual en cuanto al modo de concebir, expresar e interpretar el derecho, tal como propugnó en su día Franz Wieacker, resultado del conocimiento fragmentario y dificultoso que se tenía del derecho oficial ${ }^{4}$. Derecho corrompido, mal conocido, pragmático o hecho pragmático por medio de interpretaciones forzadas o dirigidas desde el poder, pero derecho útil, vivo, práctico, al servicio de la colectividad que había contribuido a su distorsión. Esta finalidad no la perderá en los momentos sucesivos.

La formación de ese derecho vulgar no se interrumpe con la caída del Imperio romano, sino que subsiste. Es evidente que una comunidad que se había logrado identificar con el derecho, con su derecho, como la gran creación debida al genio romano, no podía olvidar de un día para otro ese conjunto de disposiciones que, corrompidas o malinterpretadas, seguían siendo el elemento necesario para la convivencia social. De esta manera, los textos visigodos son deudores de las soluciones romano-vulgares, siguen de cerca sus técnicas normativas, sus reflexiones jurídicas, sus modos de pensar, textos que además conservarán su vigencia avanzada la Alta Edad Media. Esta época ha sido conceptuada como de «Derecho Común visigodo ${ }^{5}$, por la persistencia del Liber, completada por el surgimiento de una gama de derechos especiales, ya de corte señorial, ya de tipo municipal, condensados en los fueros. La persistencia de ese derecho romano vulgar marca una primera etapa de cierta unidad jurídica bajo la apariencia de una auténtica dispersión: el derecho visigodo se erige en la pauta jurídica que otorga cierta uniformidad al mosaico de reinos hispánicos, pero tras su lagunas y obsolescencias se empieza a dibujar cada vez con mayor intensidad la divergencia, la pluralidad, la fragmentación, que conducirán a la generación de un anhelo de unidad consolidado en siglos posteriores.

Pero el derecho romano va a experimentar una segunda vida, un renacimiento en el que pasa a ocupar ese lugar de primacía de antaño, no obstante haber desaparecido el Imperio que le servía de sustento ${ }^{6}$. El se-

${ }^{4}$ Vid. la síntesis sobre esta polémica recogida en MONTANOS FERRÍN, E. y SÁNCHEZ-ARCILLA BERNAL, J., Historia del Derecho y de las Instituciones. Editorial Dykinson, Madrid, 1991. Tomo I, pp. 337-341.

${ }^{5}$ Vid. infra las referencias a esta etapa de nuestra Historia jurídica.

${ }^{6}$ Vid. CORTESE, E., Il Rinascimento giuridico medievale. 2 edizione riveduta. Bulzoni Editore, Roma, 1996, passim.

«CUADERNOS DE ESTUDIOS GALLEGOS», Tomo XLVIII, Fascículo 114, Santiago 2001. 
gundo momento, fijado tradicionalmente en el entorno de los siglos XII y XIII, coincide con el proceso de recuperación de la obra del emperador Justiniano y tiene como punto de arranque la labor de los juristas boloñeses, quienes proceden a trabajar con los materiales originales e íntegros que habían constituido la legislación justinianea a partir de las nuevas formas de razonamiento aristotélico-tomistas que se han recuperado, arrinconando el agustinismo militante que singularizó los primeros siglos medievales. Con anterioridad a esas centurias, el conocimiento del derecho romano fue parcial, restringido, limitado a ciertas selecciones o extractos de obras jurídicas que no gozaban de una autenticidad comprobable. El proceso de vulgarización, el empobrecimiento cultural y el aislamiento que vive la Europa de los primeros siglos medievales coadyuvan a que se produzca esta especie de parálisis a la que contribuyen diferentes factores. Uno de los que no debe olvidarse es la ruptura de la unidad política y comercial mediterránea, la cual dificultará los contactos con Bizancio o con los territorios más influidos por aquél. Pero se debe hablar asimismo de la ruralización de Europa, de la desaparición de las ciudades y de las más relevantes rutas de comercio, de la extensión del feudalismo con sus componentes asociados, del descenso demográfico, de la autarquía en la que vivían señores, príncipes y reyes, etc. El resultado es el triste panorama jurídico que se respira en Europa antes del siglo XII: pocas o ninguna escuela de derecho relevante (cuando existen, se orientan a formas prácticos, no teóricos); escasos juristas de prestigio -la mayor parte anónimos-; obras jurídicas rudimentarias y elementales, pensadas para la práctica judicial o extrajudicial, desprovistas de cualquier atisbo de genio creativo, de originalidad. Esas obras emplean de manera arbitraria, fragmentaria y selectiva los textos justinianeos, contribuyendo a su oscurecimiento y, por ende, a su desconocimiento ${ }^{7}$. Todo cambio a partir del siglo XII. Es este segundo período el que ahora nos interesa puesto que será el que marque el camino evolutivo de los diferentes derechos peninsulares ${ }^{8}$.

${ }^{7}$ Para el período anterior al renacimiento del derecho romano, vid. CANNATA, C. A., Historia de la Ciencia Jurídica europea. Editorial Tecnos, S.A., Madrid, 1996, pp. 130-141.

${ }^{8}$ Así ha señalado Paolo Grossi que el fenómeno de la recuperación del derecho romano no supone afirmar que con anterioridad a las centurias citadas no se aplicase o no se conociese el derecho romano. Lo que realmente implica la labor de los juristas boloñeses 
El proceso de la recepción, surgido en la Italia fragmentada del Medievo y en donde tiene una implantación más generalizada y pura, se extiende por la Europa medieval a partir del siglo XII y de una manera casi inmediata en las centurias siguientes ${ }^{9}$, apoyada en varios factores que contribuyen a superar el triste panorama de la época inmediatamente anterior, como el renacimiento urbano, la recuperación de las primitivas rutas comerciales o, sobre todo, la aparición de las universidades que se extienden por doquier, conformando el necesario aparato intelectual y educativo que será el que se encargue de formar el importante estamento de letrados y juristas, llamados a ocupar los altos puesto directivos en las cortes europeas ${ }^{10}$. La práctica totalidad de los reinos y principados occidentales tienen algún estudiante en Italia o en Francia, primeros territorios donde experimenta un auge claro e incomparable el fenómeno universitario, quien, a su vuelta y completada su formación, procede a extender la práctica totalidad de los conocimientos adquiridos. No es extraño, pues, afirmar que el Derecho Común fue, sobre todo, un derecho de juristas antes que un derecho impulsado por el poder. Los reyes europeos tuvie-

es, al margen de los nuevos presupuestos metodológicos sobre los que elaborarán sus glosas, la recuperación del trabajo sobre materiales íntegros (no, por tanto, copias mutiladas, extractadas o epitomadas), sobre materiales cuya autenticidad estaba contrastada (frente a las posibles falsificaciones de épocas anteriores) y sobre materiales que salen de su reducto meramente teórico para convertirse en normas operativas y aplicables. Cfr. GROSSI, P., El orden jurídico medieval. Marcial Pons Ediciones Jurídicas y Sociales, S.A., Madrid, 1996, pp. 162-163: «Y comenzamos por una comprobación previa: el redescubrimiento es relativo. De hecho, durante todo el primer medioevo ha permanecido un filón jurídico de algún modo romano -elemental, rudimentario, alejadísimo de los refinados cultismos del Digesto-, sobre todo en algunos territorios, al tiempo que la Iglesia se había nutrido siempre de Derecho romano. Si ahí hubo un redescubrimiento, fue el de un Derecho romano auténtico y de textos auténticos, filológicamente exactos, en conformidad a una difundida exigencia $-\mathrm{y}$ no solamente eclesiástica- de la edad gregoriana; si hubo allí redescubrimiento, fue el del Digesto como instrumento operativo, y los historiadores del Derecho romano señalan enfáticamente como relevante una fecha y una circunstancia, el 1076, y el llamado dictamen de Márturi, una asamblea judicial celebrada en Toscana en el monasterio-castillo de Márturi, fecha y circunstancia en que se propone al Digesto como material utilizado y utilizable en la práctica jurídica».

${ }^{9}$ Vid. GARCÍA Y GARCÍA, A., «El renacimiento de la teoría y la práctica jurídicas. Siglo XII», en el volumen En el entorno del Derecho Común, pp. 11-27.

${ }^{10}$ Una síntesis sobre dicho proceso de expansión en FERNÁNDEZ BARREIRO, A. y PARICIO, J., Historia del Derecho Romano y su recepción europea. Editorial Centro de Estudios Ramón Areces, S.A., Madrid, 1995, pp. 211-244.

«CUADERNOS DE ESTUDIOS GALLEGOS», Tomo XLVIII, Fascículo 114, Santiago 2001. 
ron que adaptarse al impulso incontrolable dado por el pensamiento de los letrados y plegarse a sus prácticas, costumbres y actitudes. Pero no fue en vano, ni gratuitamente. El caudal político que se esconde detrás de los textos romanos seduce de inmediato a los principales monarcas, quienes ven en aquél, en sus construcciones políticas y en su indudable prestigio el arsenal ideológico que permita consolidar su poder superior a nivel externo (con relación al papado o al emperador) e interno (señoríos, nobleza, municipios u otros poderes autónomos $)^{11}$. Surge así un Derecho llamado Común ${ }^{12}$, esto es, de general, preferente y absoluta aplicación en la totalidad de los reinos europeos, ya como derecho principal, ya subsidiario, colocándose en una situación de superioridad respecto a los diferentes derechos locales, estatutarios o particulares, por su palmaria calidad técnica no comparable, los cuales acaban siendo observados, glosados y estudiados a la luz de aquél, es decir, de acuerdo con su lenguaje y su terminología. Ese carácter general se explica por la decidida vocación universal del derecho romano, así como por los apoyos prácticos recibidos en su periplo medieval.

De esa forma, por la vía pacífica y personal, sin imposiciones, el derecho romano se va erigiendo paulatinamente en Derecho Común, junto con el canónico y el lombardo-feudal ${ }^{13}$, en el sustrato general y básico de

\footnotetext{
${ }^{11}$ Con razón proclamaba Jacques Le Goff que todo intelectual era, es y será «orgánico», esto es, al servicio del poder con mayor o menor disimulo. Vid. LE GOFF, J., Los intelectuales en la Edad Media. Gedisa Editorial, Barcelona, 1986, passim.

${ }^{12}$ Sobre la formación de la noción «Derecho Común», vid. GUZMÁN BRITO, A., «Sobre la historia de las nociones Derecho Común y Derecho Propio». Prólogo a BRAVO LIRA, B., Derecho Común y Derecho Propio en el Nuevo Mundo. Editorial Jurídica Chilena, Santiago de Chile, 1989, pp. XI-XXXVIII.

${ }^{13}$ Vid. sobre la formación y evolución del Derecho Común las aportaciones clásicas de SAVIGNY, F. C., Geschichte des römischen Rechts im Mittlealter. Becker and Co., Wiesbaden-Biebrich, 1834, 7 tomos; BESTA, E., Introduzione al Diritto Comune. Giuffrè, Milán, 1938; ERMINI, G., Corso di Diritto Comune. I. Genesi ed evoluzione storica. Elemento costitutivi. Fonti. $2^{\text {a }}$ edición. Giuffrè, Milán, 1946; voz «Diritto Comune», en Nuovo Digesto Italiano. Unione Tipografico-Editrice Torinese, Turín, 1938. Tomo IV, pp. 970-971; y la misma voz en Nuovissimo Digesto Italiano. Unione Tipografico-Editrice Torinese, Turín, 1957. Tomo V, pp. 826-829; VINOGRADOFF, P., Diritto romano nell'Europa medioevale. Giuffrè. Milán, 1950; CALASSO, F., Introduzione al Diritto Comune. Giuffrè, Milán, 1951; y Medio Evo del Diritto. I. Le fonti. Giuffrè, Milán, 1954; KOSCHAKER, P., Europa y el Derecho Romano. Editorial Revista de Derecho Privado, Madrid, 1955; THIEME, H., voz «Gemeines Recht», en Handwörterbuch zur
} 
todos los ordenamientos jurídicos europeos continentales sin excepción alguna. La extensión de este proceso fue asimismo general a todos los reinos hispánicos, aunque el alcance final tuviera un impacto desigual. No había competidor posible puesto que la obra de Justiniano aparecía conceptuada como la obra jurídica racional por excelencia, la misma razón encarnada. Frente al tradicionalismo del período medieval, con su dependencia consuetudinaria, que conducía a un derecho inseguro y debilitado, al arbitrio de los poderosos, el Corpus era un derecho escrito, racional, con unos postulados y reglas fijas, claras y perfectamente determinadas. Pero no debe entenderse que los juristas boloñeses y europeos en general procediesen sin más a aplicar ese derecho. Como hombres de su tiempo y conocedores, por tanto, de la realidad que el mundo jurídico debía regular, los Irnerio, Azzo, Accursio y compañía hallaron en el derecho romano, antes que nada, un caudal que les proporcionaría un modo concreto de razonar en lo jurídico, con unos principios, categorías y conceptos que procedieron de inmediato a asimilar, aplicar y extender. Creemos que en esto consistió exactamente la llamada recepción: más que un cuerpo normativo directamente aplicable, los juristas vieron en esos textos el armazón jurídico que deberían volcar sobre la sociedad de su tiempo, resultado de lo cual es la síntesis entre realidad y normatividad que singulariza todo este proceso. La recepción no supuso la simple recuperación del derecho romano, sino la adaptación del derecho romano conocido a la sociedad medieval del momento, produciendo un resultado diferenciado de los componentes que constituían su punto de partida. No era un derecho romano en sentido estricto, ni un derecho medieval puro: era el fruto de la combinación de ambos factores y es precisamente esa capacidad de adap-

deutschen Rechtsgeschichte. Erich Schmidt Verlag, Berlín, 1971. Tomo I, col. 1.5061.510; CAVANNA, A., Storia del Diritto Moderno in Europa. I. Le fonti e il pensiero giuridico. Giuffrè, Milán, 1982; PIANO MORTARI, V., Gli inizi del Diritto moderno in Europa. $2^{\mathrm{a}}$ edición. Liguori, Nápoles, 1982; MERRYMAN, J. H., La tradición jurídica romano-canónica. $2^{\mathrm{a}}$ edición. Fondo de Cultura Económica, México, 1993; BELLOMO, M., La Europa del Derecho Común. Il Cigno Galileo Galilei, Roma, 1996; y BERMAN, H. J., La formación de la tradición jurídica de Occidente. Fondo de Cultura Económica, México, 2001. La producción de la doctrina jurisprudencial más relevante se puede consultar en COING, H. (coord.), Handbuch der Quellen und Literatur der neueren europäischen Privatrechtsgeschichte. Erster Band. Mittelalter (1100-1500). C. H. Beck'sche Verlagsbuchhandlung, Munich, 1973.

«CUADERNOS DE ESTUDIOS GALLEGOS», Tomo XLVIII, Fascículo 114, Santiago 2001. 
tación lo que permitió la persistencia en el tiempo del sistema jurídico del Derecho Común, su maleabilidad, su perfecto ensamblaje con el instante que debía ser subsumido por la regla jurídica, y la diversidad de evoluciones que se produjeron a partir de la existencia de unos moldes comunes.

La forma específica en que dicha recepción se materializó en la Península Ibérica nos permite observar unas diferencias sustanciales de las que se extraen diversas intensidades en el proceso y las consecuencias distintas en orden a la consolidación final del Derecho Común como derecho insertado en cada uno de los reinos. Se ha hablado de territorios en donde sí se produjo una verdadera recepción (el Derecho Común es expresamente recibido y pasa a formar parte inherente del ordenamiento jurídico del reino), como en Cataluña o en Mallorca; territorios donde hay penetración y no recepción propiamente dicha, como Valencia, en los que no se da un impulso oficial, sino un comportamiento de las instancias jurídicas en el sentido de admitirlo, a pesar de no contar con el refrendo de las autoridades superiores; $\mathrm{y}$, en fin, de territorios en los que se produjo una fuerte resistencia y rechazo, caso de Aragón ${ }^{14}$. Ello simplemente quiere poner de manifiesto la existencia de posturas marcadamente diferenciadas respecto a las relaciones entre el Ius Proprium y el derecho foráneo a la hora de disciplinar el sistema de integración de cada ordenamiento jurídico. Habrá, pues, reinos o territorios en los que la facilidad para la asimilación de las soluciones romano-canónicas sea total y esa facilidad esté auspiciada por el propio poder político y por el estamento de letrados y prácticos del derecho en general, frente a otros en los que los obstáculos son continuados. En ambos casos, por una u otra vía, la solución final conducirá a un triunfo sin paliativos del nuevo derecho surgido en los siglos centrales del Medievo.

Estos diferentes ensayos jurídicos son los que permiten distinguir entre lo que se ha llamado propiamente «recepción» y lo que fue la «penetración». La primera, como ya hemos expuesto, supone un marcado proceso en el cual se procede a la instauración de un novedoso orden jurídico, que reemplaza o pasa a coexistir con el anterior para ir paulatinamente arrinconándolo. Mientras, por su parte, la «penetración», presupuesto

\footnotetext{
${ }^{14}$ Vid. LALINDE ABADÍA, J., «El Derecho Común en los territorios ibéricos de la Corona de Aragón», en España y Europa. Un pasado jurídico común. Actas del I Simposio Internacional del Instituto de Derecho Común. Universidad de Murcia, Murcia, 1986, pp. 145-178.
} 
cronológico de la posterior recepción, aludiría a aquellas actuaciones espontáneas, privadas y anónimas en la mayor parte de los casos, mediante las cuales se da pie a la inserción tímida de ciertos comportamientos o instituciones del nuevo orden jurídico que suponen colocar el derecho en la senda de una nueva formulación, camino de otras direcciones distintas de las tradicionales. Este movimiento supone una combinación o mezcla entre las tradiciones jurídicas que se proyectan de forma conflictual, tomando aspectos de una y de otra. La «penetración» es, si se permite la expresión, el ensayo, la preparación, el prolegómeno, que luego acabará desembocando en la recepción como proceso culminante y complejo de esta lucha jurídica, momento en el cual los ensayos anteriores pasan de su timidez e indolencia inicial a convertirse en pautas decididas, en modelos claros que marcan el camino a seguir en la nueva ordenación jurídica que se extiende sin paliativos y se impone sobre la anterior: ahora todo responde en su formulación a los caracteres, conceptos y expresiones del nuevo derecho que se está implantando. Uno es la potencia; el otro, el acto pleno y lleno de sentido jurídico. Uno el esbozo; el otro, la culminación.

$\mathrm{Al}$ glosar las diferencias en orden a la creación del derecho que se detectan entre la España nuclear (Castilla y Vascongadas) y la España periférica (Corona de Aragón), el profesor Lalinde Abadía había subrayado las diferentes posturas adoptadas respecto al Derecho Común que en ningún caso se presentaban bajo el prisma de unidad. Mientras que en el caso castellano se puede hablar de un verdadero intento de «nacionalización» por medio de las Partidas, al que sigue todo el esplendor del derecho romano en época moderna merced a la labor de tribunales y juristas ${ }^{15}$, en la Corona aragonesa hay posiciones radicales en relación con el Ius Commune, que van desde su asimilación más completa hasta su rechazo mas absoluto ${ }^{16}$. De esta forma, se pueden atisbar comportamientos previos en relación al Derecho Común que van a condicionar de modo claro y preciso el proceso de asunción de las soluciones jurídicas que este ordenamiento racional y culto comportaba: fuertemente condicionados por esos derechos justinianeo y canónico, Cataluña y Mallorca se convierten

${ }^{15}$ Cfr. LALINDE ABADÍA, J., «La creación del Derecho entre los españoles», en Anuario de Historia del Derecho Español, XXXVI (1966), pp. 337-338.

${ }^{16}$ Cfr. LALINDE ABADÍA, J., «La creación del Derecho entre los españoles», en Anuario de Historia del Derecho Español, XXXVI (1966), pp. 368-369. 
en paradigmas de la adaptación plena del Ius Commune a los efectos de integrar las posibles lagunas existentes en el derecho tradicional, por medio del recurso a las fuentes romanas. Valencia permite observar una matización que conduce, no obstante, a resultados parecidos, por cuanto que no hay una remisión expresa al mundo romano-canónico, sino a su trasunto, de acuerdo con la idea defendida por los juristas medievales: las lagunas legales se integrarán acudiendo, dice el prefacio de los Furs, a la razón natural y a la equidad ${ }^{17}$. Ambas potencias racionales, obvia decirlo, se hallaban plasmadas por escrito en los textos romanos y canónicos, y lo mismo sucedía en el caso aragonés a tenor de lo que sancionaba la compilación elaborada por Jaime I, conocida como Código de Huesca ${ }^{18}$.

Como se ha visto, el Derecho Común se constituyó en parte integrante del ordenamiento jurídico por decisión propia del poder político, esto es, pasó a formar parte del sistema de fuentes de forma oficial, mientras que en otras regiones la penetración de aquél tuvo lugar aprovechando aquellos resquicios que permitía o toleraba el propio ordenamiento, sin que ello implicase una decisión pública al respecto en sentido positivo o negativo, antes bien motivó opiniones y decisiones públicas en contrario. Ejemplo de lo primero: Cataluña ${ }^{19}$,

${ }^{17}$ Fori Antiqui Valentiae. Edición crítica de Manuel Dualde Serrano. C.S.I.C. Escuela de Estudios Medievales, Madrid-Valencia, 1950-1967. Praefatio: «Hiis itaque prelibatis, ubi dicte consuetudines non poterunt habundare, ad naturalem rationem et equitatem iudicantes possunt licite prope rare».

${ }^{18}$ Vidal Mayor. Edición, introducción y notas al manuscrito por $\mathrm{M}^{\mathrm{a}}$. de los Desamparados Cabanes Pecour, Asunción Blasco Martínez y Pilar Pueyo Colomina. Libros Certeza, Zaragoza, 1996. Prólogo, pp. 17-18: «Ont por esto en la virtud de la nuestra fe a todos los bailles, justicias, çalmedinas, jurados, juges, alcaldes, juncteros et officiales, et todos aqueillos que officio de conocer et de judgar pleitos es liurado et comendado, et otrosí a todos los nuestros fieles mandamos que aquestos fueros tant solament usen en todas las cosas et en todos los pleitos et en als determinaciones daqueillos; mas empero aillí do los devanaditos fueros no abastaran, al natural seso et memoria sea recorrido (...)».

${ }^{19}$ Vid. IGLESIA FERREIRÓS, A., «La creación del Derecho en Cataluña», en Anuario de Historia del Derecho Español, XLVII (1977), pp. 99-423; «¿El primer testimonio de la recepción del derecho romano en Cataluña?», en Revista Jurídica de Cataluña, 2 (abril-junio 1978), pp. 281-311; «La Cataluña altomedieval y el Código de Justiniano», en Revista Jurídica de Cataluña. Año LXXXII, 3 (1983), pp. 85-107; «Cataluña y el Derecho Común", en El Dret Comú i Catalunya. Actes del VI Simposi Internacional. Barcelona, 31 de maig-1 de juny de 1996. Edició d'Aquilino Iglesia Ferreirós. Fundació Noguera. Associació Catalana d'Història del Dret Jaume de Montjuïc, Barcelona, 1997, pp. 19-65; y «El Derecho Común y Cataluña», en ibidem, pp. 305-406. 
Mallorca $^{20} \mathrm{o}$ Valencia ${ }^{21}$, donde la presencia de derecho romano es mucho más intensa que en otros territorios. De lo segundo, pueden dar buena muestra Aragón ${ }^{22}$, Navarra ${ }^{23}$ o la Corona de Castilla ${ }^{24}$, y, para el caso concreto que nos ocupa, Galicia ${ }^{25}$, en donde la recepción, aun dándose, se manifiesta de una forma solapada, más difusa.

El fenómeno de la recepción pone sobre la mesa de debate dos cuestiones esenciales que marcan el tránsito hacia una nueva experiencia jurídica, entendida en el sentido que le dio Capograssi: el modo de vivir, sentir y reflejar el derecho por una comunidad determinada ${ }^{26}$.

Primeramente, el cambio en la concepción misma de la esencia del derecho, de su sustancialidad y sus fundamentos. Se trata de una cuestión de corte filosófico, teórico, llena de consideraciones dogmáticas: se ha

${ }^{20}$ Vid. PIÑA HOMS, R., El Derecho histórico en el reino de Mallorca. Fuentes e instituciones. Ediciones Cort, Palma de Mallorca, 1993, pp. 83-89 y pp. 93 ss.

${ }^{21}$ Vid. BARRERO GARCÍA, A. M., «El Derecho romano en los Furs de Valencia de Jaime I», en Anuario de Historia del Derecho Español, XLI (1971), pp. 639-664; y LALINDE ABADÍA, J., «El sistema normativo valenciano», en Anuario de Historia del Derecho Español, XLII (1972), pp. 307-330.

${ }^{22}$ Vid. LALINDE ABADÍA, J., Los Fueros de Aragón. Librería General, Zaragoza, 1976, pp. 45-62.

${ }^{23}$ Vid. LACARRA, J. M., «Sobre la recepción del Derecho romano en Navarra», en Anuario de Historia del Derecho Español, XI (1934), pp. 457-467. Matiza un poco la clásica visión de Lacarra, LALINDE ABADÍA, J., «El sistema normativo navarro», en Anuario de Historia del Derecho Español, XL (1970), pp. 85-108, explicando en sus conclusiones que «el normativismo historicista navarro es de raíz popular y antierudita -opuesto entonces por definición al Derecho Común- procediendo la recepción del Derecho común en el siglo XVI por reacción anticastellana y sin auténticos precedentes anteriores».

${ }^{24}$ Con carácter general, vid. MARTÍNEZ DÍEZ, G., «Los comienzos de la recepción del Derecho Romano en España y el Fuero Real», en Diritto Comune e Diritti Locali nella Storia dell'Europa. Atti del Convegno de Varenna, ed. cit., pp. 253-262; BARRERO GARCÍA, A. M., «El Derecho local, el territorial, el general y el Común en Castilla, Aragón y Navarra», en ibidem, pp. 265-284; y SÁNCHEZ-ARCILLA BERNAL, J., «La pervivencia de la tradición jurídica romana en España y la recepción del Derecho Común», en ob. cit., pp. 400-403.

${ }^{25}$ Algunas reflexiones sobre el caso gallego en IGLESIA FERREIRÓS, A., «Breviario, recepción y Fuero Real: tres notas», en Estudios jurídicos. Homenaje al profesor Alfonso Otero. Universidad de Santiago de Compostela, Santiago de Compostela, 1981, pp. 129-151, en especial, pp. 140-148.

${ }^{26}$ Cfr. CAPOGRASSI, G., «Il problema de la scienza del diritto», en Opere. Giuffrè, Milán, 1959. Tomo II, pp. 415 ss. 
producido, por el juego del nuevo derecho romano, una mutación radical en cuanto a los elementos que caracterizan el orden jurídico y forman su esencia y sus caracteres más íntimos. Influidos por el pensamiento aristotélico y con el deseo de efectuar una tímida secularización de lo jurídico, los juristas medievales se lanzan a la explicación novedosa de los conceptos básicos que se hallan en las primeras páginas de la obra justinianea. La influencia de Santo Tomás es también relevante puesto que el Aquinatense había expresado la idea de que la justicia era el objeto principal del derecho. Ni Dios, ni la tradición, ni ningún otro componente ultraterreno aparecían en estas nuevas visiones. Eran el hombre y sus propias aspiraciones quienes reformulaban lo jurídico y lo hacían con arreglo a unos criterios moderadamente racionales. El profesor GarcíaPelayo se refería a ese tránsito, marcando las notas más relevantes de la evolución operada: frente a un derecho altomedieval consuetudinario, de raíz teológica, basado en el privilegio, garante de la paz y de escaso nivel técnico, se opone un nuevo derecho, de tipo iuscéntrico, apoyado en una suerte de justicia secularizada, que descansa en la ley como norma escrita básica, con tendencias igualitarias, general en el sentido de un derecho que tiende a superar los localismos a los que estaba abocado por el peso de la costumbre, profundamente científico y de alto nivel conceptual y técnico ${ }^{27}$. De un sistema consuetudinario, amparado en un rey más juez que legislador, se pasa a un sistema legalista, en el que el monarca recupera el monopolio creador del derecho al asimilarse los principios políticos y legislativos dimanantes de los textos romanos ${ }^{28}$.

${ }^{27}$ Vid. GARCÍA-PELAYO, M., «La idea medieval del derecho», en Obras Completas. Centro de Estudios Constitucionales, Madrid, 1991. Tomo II, pp. 1.073-1.118. Sobre la concepción altomedieval del derecho, deben consultarse además el clásico título de KERN, F., Derechos del rey y derechos del pueblo. Ediciones Rialp, S.A., Madrid, 1955, pp. 124-139; y la más reciente aportación de GURIÉVICH, A., Las categorías de la cultura medieval. Taurus Humanidades, Madrid, 1992, pp. 181-239.

${ }^{28}$ Idea que ha expuesto el profesor Pacheco Caballero, al contraponer los caracteres que presenta la creación del derecho en la Alta y en la Baja Edad Media. Vid. PACHECO CABALLERO, F. L., «Ley, costumbre y uso en la experiencia jurídica peninsular bajomedieval y moderna», en El Dret Comú $i$ Catalunya. Actes del IV Simposi Internacional. Homenatge al professor Josep M. Gay Escoda. Barcelona, 27-28 de maig de 1994. Edició d'Aquilino Iglesia Ferreirós. Fundació Noguera. Associació Catalana d'Història del Dret Jaume de Montjuïc, Barcelona, 1995, pp. 75-146; y «Reyes, leyes y derecho en la Alta Edad Media castellano-leonesa», en El Dret Comú i Catalunya. Actes 
El segundo aspecto al que nos referíamos alude al juego de la vigencia de las propias normas del ordenamiento jurídico y su extensión. Si el período altomedieval ha sido caracterizado con razón como sistema de «Derecho Común visigodo» como expuse anteriormente, el proceso que se inicia a partir del siglo XII-XIII sienta las estructuras de un nuevo sistema de Derecho Común, esta vez romano-canónico, que reemplazará al anterior. La persistencia del derecho visigodo, encarnado en el Liber Iudiciorum, es idea antigua ya defendida por el padre de nuestra moderna Historia del Derecho, Francisco Martínez Marina ${ }^{29}$. Ese texto constituiría el derecho general de los antiguos territorios del Regnum Gothorum, al que se le van añadiendo y completando, por la propia dinámica social y la obsolescencia de algunas de sus disposiciones, nuevas normas materializadas en costumbres, usos, prácticas judiciales, cartas de población y, como fase final de la evolución, en los fueros. Constituyen la manifestación escrita de un derecho complementario, nacido para auxiliar o suplir, según los casos, la legislación gótica. Y por ese mismo motivo, su aparición está ligada íntimamente a una pluralidad o disparidad de soluciones que conducen irremisiblemente al localismo, a la existencia de soluciones puntuales y precisas con las que cuales atender a las necesidades o exigencias concretas de tal localidad, comarca, villa o ciudad. La fuente última de este derecho especial será la decisión de los señores o la aprobación efectuada por los municipios, por lo que se habla de un derecho de tipo señorial o municipal, según los casos, en función de la autoridad que ratifique esas supuestas emanaciones populares. El derecho heredado de la Alta Edad Media será un

del V Simposi Internacional. Barcelona, 26-27 de maig de 1995. Edició d'Aquilino Iglesia Ferreirós. Fundació Noguera. Associació Catalana d'Història del Dret Jaume de Montjuïc, Barcelona, 1996, pp. 165-206.

${ }^{29}$ Cfr. MARTÍNEZ MARINA, F., Ensayo histórico-crítico sobre la legislación y principales cuerpos legales de los reinos de León y Castilla, especialmente sobre el Código de las Siete Partidas de D. Alonso el Sabio. $3^{\text {a }}$ edición. Imprenta de la Sociedad Literaria y Tipográfica, Madrid, 1845. Libro I, $\mathrm{n}^{\circ}$. 41-42, pp. 44-52; y Libro V, $\mathrm{n}^{\circ}$. 1-2, pp. 139-140. Postura seguida hoy de manera casi unánime merced a los trabajos de OTERO VARELA, A., «El Códice López Ferreiro del Liber Iudiciorum», en Anuario de Historia del Derecho Español, XXIX (1959), pp. 557-573; e IGLESIA FERREIRÓS, A., «Derecho municipal, derecho señorial, derecho regio», en Historia, Instituciones, Documentos, 4 (1977), pp. 115-197.

«CUADERNOS DE ESTUDIOS GALLEGOS», Tomo XLVIII, Fascículo 114, Santiago 2001. 
conglomerado de privilegios, exenciones, inmunidades, libertades y franquicias, a las que se trata de poner fin mediante una tendencia a la unificación jurídica, que tendrá como adalid a Alfonso X el Sabio para el caso castellano, quien, lejos de apoyarse en el derecho de corte tradicional, tomará como elemento unificador el derecho romano justinianeo y el derecho canónico ${ }^{30}$.

La finalidad de estas breves líneas, nacidas con ánimo de orientar más que de agotar la compleja problemática que el tema acotado pudiera suscitar, caminará en la dirección indicada y tratará de responder a las siguientes cuestiones: ¿Fue Galicia un territorio en el que se produjo un proceso análogo de penetración al de otros reinos hispánicos? En caso afirmativo, ¿cuáles fueron las vías y cuáles los motivos que auspiciaron esa inserción en el universo del Derecho Común?. En segundo lugar, ¿cómo operó en la práctica ese proceso de recepción? ¿cuáles fueron sus manifestaciones institucionales concretas? ${ }^{31}$. Bajo estos dos parámetros se ha intentado formular coherentemente una especie de pequeña historia de la penetración/recepción en Galicia y de la indiscutible trascendencia que el Derecho Común tuvo a la hora de disciplinar u orientar la formación de la conciencia jurídica de un territorio que, por circunstancias históricas que ahora no conviene relatar, se convirtió en titular de esa condición de

\footnotetext{
${ }^{30}$ Sobre la obra alfonsina, vid. la síntesis de SÁNCHEZ-ARCILLA BERNAL, J., «La obra legislativa de Alfonso X el Sabio. Historia de una polémica», en El scriptorium alfonsi: de los libros de astrología a las Cantigas de Santa María. Editorial Complutense, Madrid, 1999, pp. 17-81.

${ }^{31}$ A falta de un trabajo que aborde en profundidad la Historia jurídica de Galicia, escrito desde la óptica de la Historia del Derecho, pueden consultarse como referencias generales, sin grandes precisiones al respecto, las siguientes obras de RODRÍGUEZ ENNES, L., «Proceso histórico de formación del Derecho Civil gallego», en Dereito. Revista Xurídica da Universidade de Santiago de Compostela, vol. 5, 2 (1996), pp. 251286; Aproximación a la historia jurídica de Galicia. Xunta de Galicia, Santiago de Compostela, 1999, pp. 51-68; e Historia do Dereito de Galicia. Servicio de Publicacións. Universidade de Vigo, Vigo, 2000, pp. 36-54. Para lo acontecido en épocas posteriores, vid. MONTANOS FERRÍN, E., «Notas sobre la práctica jurídica gallega en el siglo XVIII», en Anuario de Historia del Derecho Español, LII (1982), pp. 711-731; «El Ius Commune en los albores de la Codificación en el reino de Galicia: fundamento de su literatura jurídico-doctrinal; su mantenimiento en los Planes de Estudio de la Facultad de Leyes compostelana y su aplicación en la Real Audiencia», en Anuario da Facultade de Dereito da Universidade da Coruña, 1 (1997), pp. 387-400; y «Reflejo jurídico-doctrinal del sistema del Ius Commune en el reino medieval de Galicia», en ibidem, 3 (1999), pp. 417-431.
} 
«territorio foral» que nació al amparo de todo el proceso codificador decimonónico. Conocer esta etapa histórica sirve para verificar si dicha calificación como territorio foral es o no acertada, incluso en el marco del actual ordenamiento constitucional

\section{2.- EL CASO GALLEGO: FACTORES QUE IMPULSARON LA RECEPCIÓN}

La incorporación de Galicia al reino de Asturias, después de León, y posteriormente Corona de Castilla, se produce en fecha temprana (entre los siglos VIII y IX) y supuso la inserción del antiguo reino dentro de los esquemas político-constitucionales de la monarquía leonesa, aún conservando de manera meramente simbólica y formal el calificativo de reino, incluso hasta la Edad Moderna. Derivado de esa imbricación plena, Galicia careció de las instituciones administrativas mediante las cuales se articuló el derecho propio y adecuado a su realidad, a diferencia de lo que aconteció en otros territorios peninsulares. Asimismo no se dieron peculiaridades político-administrativas significativas: no hubo Cortes y no hubo posibilidad de incidir en las decisiones normativas de los monarcas a través de un cauce institucionalizado. Ello supone que Galicia se adecuó con mayor o menor fidelidad al sistema normativo del reino castellanoleonés y a su esquema de fuentes. Galicia fue un reino medieval, pero un reino desprovisto de las singularidades que caracterizaron a sus coetáneos y sobre el que se proyectaron las ansias expansionistas de sus vecinos castellanos, leoneses y portugueses ${ }^{32}$.

${ }^{32}$ Para un panorama general del período estudiado, vid. RODRÍGUEZ GONZÁLEZ, A., «A época medieval», en Historia de Galicia. Cursa Editorial. Editorial Planeta, S.A., Barcelona, 1980. Tomo I, pp. 107-200; PORTELA SILVA, E. y PALLARES MÉNDEZ, M. C., Galicia na época medieval, en Galicia Historia. Hércules de Edicións, S.A., La Coruña, 1991. Tomo II, pp. 109-117 y pp. 233 ss.; VV. AA., Historia de Galicia. 2. Baja Edad Media y comienzos de la Edad Moderna. Faro de Vigo, S.A., Vigo, 1991, pp. 329 ss.; VILLARES PAZ, R., Historia de Galicia. $3^{\mathrm{a}}$ reimpresión. Alianza Editorial, Madrid, 1993, pp. 64-78; y ANDRADE CERNADAS, J. M. y PÉREZ RODRÍGUEZ, F. J., Historia de Galicia. Galicia Medieval. Vía Láctea Editorial, La Coruña, 1995. Tomo III; pp. 160 ss. La conformación del régimen señorial gallego se puede estudiar brevemente en PORTELA SILVA, E. et alii, voz «Señorío», en Gran Enciclopedia Gallega. Silverio 
La dependencia respecto al vecino reino leonés se detecta desde los primeros siglos medievales. La repoblación de un territorio que nunca estuvo totalmente despoblado provocó la consolidación de las estructuras de poder señoriales ${ }^{33}$. Galicia se convirtió en un territorio fuertemente dominado por estirpes laicas o instituciones religiosas gracias a la munificencia de los monarcas que premiaron con abundantes tierras a los nobles, quienes se convertían en excelentes suministradores de ejércitos y tropas para las labores militares de reconquista. Basta recordar el enorme poderío del que gozaron los obispos gallegos, titulares de extensos dominios y que señoreaban además las principales ciudades del reino, o de los monasterios, cuyos cotos constituían auténticos reinos en miniatura donde los abades ejercían las principales funciones de gobierno y de justicia. La presencia regia era más simbólica que efectiva: los agentes reales, cargos que normalmente recaían en alguno de los poderosos, extendían sus funciones a lo largo de un territorio dividido en múltiples zonas exentas o inmunes. A todo ello debemos sumar un componente muy marcado de ruralización. Conforme a los datos proporcionados por Manuel Rubén García Álvarez, la densidad de población de Galicia sería elevada, si se compara con las de otras regiones peninsulares, mas se hallaba mal repartida y, sobre todo, concentrada en los campos, lejos de las ciudades, si es que en esas centurias se podía calificar así a los principales núcleos urba$\operatorname{nos}^{34}$. Todo ello comporta unas correlativas notas de conservadurismo y tradición, de parálisis, que se ponen de manifiesto en la pervivencia de una estructura social fuertemente jerarquizada con figuras jurídicas erradicadas de otros territorios como los colonos o los tributarios, antiguos pequeños propietarios que por mor de las precarias circunstancias económicas tuvieron que adscribirse a las tierras que anteriormente culti-

Cañada Editor, Santiago de Compostela, 1979. Tomo XXVIII, pp. 124-154; VV. AA., Poder y sociedad en la Galicia medieval. Tórculo Edicóns, Santiago de Compostela, 1992; y GARCÍA ORO, J., Galicia en la Baja Edad Media. Iglesia, señorio y nobleza. Editorial Toxosoutos. Serie Trivium, Noia, 1999, pp. 11 ss.

${ }^{33}$ Vid. SÁNCHEZ-ALBORNOZ, C., «Despoblación y repoblación de las tierras galaico portuguesas», en Estudios sobre Galicia en la temprana Edad Media. Edición preparada por el Instituto Padre Sarmiento de Estudios Gallegos, La Coruña, 1981, pp. 185-222, destacando el papel capital de Alfonso III entre los siglos IX y X.

${ }^{34}$ Vid. GARCÍA-ÁLVAREZ, M. R., Galicia y los gallegos en la Alta Edad Media. Editorial Pico Sacro, Santiago de Compostela, 1975. Tomo I, pp. 227 ss. 
vaban y renunciar a la propiedad de las mismas ${ }^{35}$. El carácter conservador de Galicia, inherente a toda sociedad de tipo rural y de economía de subsistencia de tipo agrícola y ganadero, detectado en la pervivencia de numerosas instituciones como el tributo cuadragesimal de raigambre romana, sirve para explicar a la perfección esa continuidad que se puede atisbar en el campo del derecho. Asimismo se ha dicho que Galicia es el último territorio peninsular en que se abandona el uso de la letra gótica, sustituida por la minúscula carolina, prueba una vez más de ese apego de tintes estáticos al pasado ${ }^{36}$. En todos los estratos de su cultura, Galicia aparecía apegada firmemente a lo pretérito.

Ese carácter permitió la continuidad de la vida jurídica sin grandes sobresaltos. De esa forma, se admite sin dificultad la vigencia del Liber Iudiciorum, como se puede colegir de la presencia de abundantes manuscritos o noticias de los mismos, así como textos en los que se alude expresamente a la aplicación de la ley gótica. Como acontecía en el resto de los reinos, la obsolescencia del derecho visigodo se vio completada por la aparición de costumbres, usos y prácticas recogidas posteriormente en los fueros, o bien por la extensión de los de otras localidades. En el caso gallego, es constatable la vigencia del orden visigodo, que se vería reforzado por la famosa restauración atribuida a Alfonso II de Asturias quien recuperó el orden gótico en el palacio y en la iglesia, a tenor del testimonio recogido en la Crónica de Albelda. La presencia de numerosos códices en los que se han reproducido copias del Liber, frecuentes en monasterios y en catedrales, pone de manifiesto la pervivencia del texto jurídico visigodo, si bien la pervivencia apuntada no indica la inmutabilidad de aquél, ni la uniformidad de las copias existentes, ni un idéntico grado de aplicación y de conocimiento ${ }^{37}$. En una

${ }^{35}$ Vid. GARCÍA-ÁLVAREZ, M. R., Galicia y los gallegos en la Alta Edad Media. Tomo II, pp. 351 ss.

${ }^{36}$ Vid. SÁNCHEZ-ALBORNOZ, C., «El tributum quadragesimale. Supervivencias fiscales romanas en Galicia», en Estudios sobre Galicia en la temprana Edad Media, ed. cit., pp. 269-284.

${ }^{37}$ Vid. DÍAZ Y DÍAZ, M. C., «La Lex Visigothorum y sus manuscritos. Un ensayo de reinterpretación», en Anuario de Historia del Derecho Español, XLVI (1976), pp. 163224; y Códices visigóticos en la monarquía leonesa. Centro de Estudios e Investigación San Isidoro, León, 1983, pp. 149-246; FAULHABER, Ch. B., Libros y bibliotecas en la España medieval: una bibliografia de fuentes impresas. Grant \& Cutler, Londres, 1987, pp. 137-144; y RODIÑO CARAMÉS, C., «A lex gotica e o liber iudicum no reino de León», en Cuadernos de Estudios Gallegos, tomo XLIV, 109 (1997), pp. 9-52.

«CUADERNOS DE ESTUDIOS GALLEGOS», Tomo XLVIII, Fascículo 114, Santiago 2001. 
época de escasa presencia de la cultura escrita, solamente se copiaba aquello que tenía un interés fundamental para el desarrollo de la vida cotidiana $\mathrm{y}$ el derecho recogido en el texto mencionado servía de forma absoluta para regular la mayor parte de las actuaciones diarias de los habitantes del reino. Ello no impide, como resulta obvio, la existencia de incorrecciones, omisiones y demás defectos en las copias conservadas, en consonancia con las limitaciones culturales del momento, y que tales deficiencias pudiesen tener después su correlativo aplicación en la práctica contribuyendo a distorsionar así el derecho oficial o pretendidamente oficial.

Al lado del Liber, hemos de repetirlo, van apareciendo toda una pléyade de normas auxiliares de diversa procedencia, condensadas en los textos forales, generalmente de reducido ámbito y extensión, que completan o suplen la anterior normativa, provocando un evidente estado de pluralidad jurídica. Ese material jurídico dispar fructifica con la redacción hacia el siglo XII de los primeros textos forales típicamente gallegos, de tipo breve y de escasa originalidad: son, en su mayoría, derivados de los fueros de la ciudad de León, de los de Sahagún y de los de Benavente, los de mayor fama y relevancia en el reino, a la vez que los que mejor se adaptaban a las necesidades que los reyes trataban de hacer frente (repoblación interior y costera, esencialmente). A veces, se trataba de efectuar simples extensiones de aquellos a otras localidades a los efectos de mejorar el estatuto de sus habitantes o evitar la despoblación de ciertos lugares ${ }^{38}$. Paulatinamente comienza a desarrollarse una importante vida urbana con algunos enclaves de gran relevancia ${ }^{39}$. Los cambios sociales, políticos,

\footnotetext{
${ }^{38}$ Sin ánimo exhaustivo, los principales textos forales son producto de las labores de repoblación desarrolladas a partir del reinado de Alfonso VI y sus sucesores (Fernando II y Alfonso IX). Enumeramos los más importantes: Lugo, Santiago de Compostela y su Tierra, Monforte, Sarria, Allariz, Orense y Bonoburgo de Caldelas. En la repoblación costera, se generaron textos forales de gran importancia coincidiendo con la fundación de nuevos enclaves urbanos: Tuy, Bayona, Ribadeo, Vivero, La Coruña y Mondoñedo, entre otras, tuvieron su propio texto foral. Vid. GIBERT SÁNCHEZ DE LA VEGA, R., «El derecho municipal de León y Castilla», en Anuario de Historia del Derecho Español, XXXI (1961), pp. 695-753, en concreto referido a Galicia, pp. 698-702. Las referencias bibliográficas se pueden consultar en BARRERO GARCÍA, A. M. y ALONSO MARTÍN, M. L., Textos de Derecho Local español en la Edad Media. Catálogo de fueros y costums municipales. C.S.I.C. Instituto de Ciencias Jurídicas, Madrid, 1989.

${ }^{39}$ Vid. GAUTIER-DALCHÉ, J., Historia urbana de León y Castilla en la Edad Media (Siglos IX-XIII). $2^{\text {a }}$ edición. Siglo XXI de España Editores, Madrid, 1989, pp. 67 ss.
} 
económicos y de otra naturaleza provocan la creación de un caldo de cultivo óptimo para que se pasase una transición hacia un nuevo modelo jurídico, de raíces opuestas al que hasta entonces se había estilado. El cambio en la sociedad, entendido en un sentido amplio que abarcaría todas sus manifestaciones, tenía que acabar desembocando en un cambio jurídico.

De la misma manera, en la época de tránsito hacia la nueva experiencia jurídica bajomedieval, los síntomas y tendencias detectados para el caso castellano se dejarán ver en el territorio gallego: la conexión con el fenómeno de la recepción se producirá asimismo en Galicia, pero interesan destacar los mecanismos concretos a través de los que operó ese proceso, las posibles causas que lo impulsaron y los efectos puntuales que de él se derivaron. Apuntamos, siguiendo a Gibert, los dos principales motivos que propiciaron la penetración ${ }^{40}$. Por un lado, la sólida organización y presencia eclesiástica, de lo que darán buena prueba las bibliotecas y escuelas donde se enseñan las principales artes del momento, fruto de una riqueza y de una instalación perfecta del estamento religioso en prácticamente todos sus niveles. Por otro, el papel esencial del camino de Santiago, como vía espiritual que permitió el tránsito libre de personas, mercancías e ideas: los tres elementos influyeron decisivamente en la consolidación del cambio jurídico que se estaba operando, en la traslación de esquemas, libros, reflexiones, a lo largo y ancho de la vía jacobea ${ }^{41}$. Como bien había señalado el profesor Pérez Martín, siguiendo a Van Caenegen, el Derecho Común tiene en esencia dos vías para extenderse: los hombres y los libros, el componente humano y el componente material, los juristas o letrados y sus correspondientes obras intelectuales ${ }^{42}$. En eso, Galicia no fue la excepción.

El camino hacia el Nuevo Derecho, constituido sobre todo por el romano y el canónico, ha dejado una primera huella de tipo bibliográfico, un primer factor que se ha de seguir rastreando las creaciones intelectua-

\footnotetext{
${ }^{40}$ Cfr. GIBERT SÁNCHEZ DE LA VEGA, R., «Enseñanza del derecho en Hispania durante los siglos VI a XI», en Ius Romanum Medii Aevi. Pars I, 5, b, cc. Giuffrè, Milán, 1967 , p. 33.

${ }^{41}$ Vid. LACARRA, J. M., URÍA, J. y VÁZQUEZ DE PARGA, L., Las peregrinaciones a Santiago de Compostela. C.S.I.C., Madrid, 1948-1949. 3 tomos.

${ }^{42}$ Cfr. PÉREZ MARTÍN, A., «El estudio de la recepción del Derecho Común en España», en VV. AA., Seminario de Historia del Derecho y Derecho Privado, ed. cit., p. 245.
} 
les del mundo jurídico del momento. Antes hemos destacado cómo el derecho altomedieval era en esencia un derecho de origen popular, consuetudinario, amparado en la tradición, por lo que su nivel técnico-científico era muy bajo, por no decir nulo. Tanto la formulación de las normas jurídicas como los pocos tratados de derecho que se conservan brillan por la ausencia de construcciones dogmáticas o doctrinas sobre las diferentes instituciones. Al contrario, se trata de un derecho eminentemente práctico, desprovisto de cualquier concesión a lo que no fuese la pura y simple aplicación del derecho. Por esta razón, la bibliotecas altomedievales destacan por la carencia de textos de derecho, con la sola excepción del Liber, de la colección canónica Hispana, algún penitencial o en contadas ocasiones algún otro texto canónico como el Decreto de Buchardo de Worms ${ }^{43}$. Predominan, antes bien, los libros de tipo litúrgico, las copias de las Sagradas Escrituras y tratados de corte espiritual o místico. El saber laico apenas aparece representado por las Etimologías de San Isidoro de Sevilla y las Institutiones de Casiodoro.

Al mismo tiempo, esa carencia de material jurídico obedecía a la concepción que sobre el mismo se tenía en ese período anterior a la aparición de la Escuela de Bolonia. El derecho no se entendía en aquel entonces como un saber especializado: no existían escuelas dedicadas a la formación de juristas, salvo las de notarios en el reino aragonés ${ }^{44}$, y se carecía de una conciencia científica de que el derecho constituyese un saber diferenciado de la Dialéctica (ciencia en la que se hallaba integrado y que

${ }^{43}$ Vid. SÁNCHEZ-ALBORNOZ, C., «Notas sobre los libros leídos en el reino de León hace mil años», en Cuadernos de Historia de España, I (1944), pp. 222-238; GARCÍA-ÁLVAREZ, M. R., «Los libros en la documentación gallega de la Alta Edad Media», en Cuadernos de Estudios Gallegos, tomo XX, 62 (1965), pp. 292-329; DÍAZ Y DÍAZ, M. C., Códices visigóticos en la monarquia leonesa. Centro de Estudios e Investigación San Isidoro, León, 1983, pp. 149-246; y «Bibliotecas en los reinos hispánicos en el siglo XII», en II Curso de Cultura Medieval. Alfonso VIII y su época. Centro de Estudios del Románico, Madrid, 1992, pp. 61-69; y RUÍZ ASENCIO, J. M., «Escribas y bibliotecas altomedievales hispanos», en La enseñanza en la Edad Media. X Semana de Estudios Medievales. Nájera, 1999. Instituto de Estudios Riojanos, Logroño, 2000, pp. 151-174.

${ }^{44}$ Cfr. GIBERT SÁNCHEZ DE LA VEGA, R., «Enseñanza del derecho en Hispania durante los siglos VI a XI», en Ius Romanum Medii Aevi. Pars I, 5, b, cc. Giuffrè, Milán, 1967, pp. 24-54; y GARCÍA Y GARCÍA, A., «De las escuelas visigóticas a las bajomedievales. Punto de vista histórico-jurídico», en La enseñanza en la Edad Media, ed. cit., pp. 39-59. 
junto con la Gramática y la Retórica, formaban el Trivium, primer paso en la formación del estudiantado medieval que luego se completaría con el Quadrivium).

Sin embargo, el panorama muda radicalmente desde el preciso instante en que se comienzan a detectar los primeros síntomas de la presencia del Nuevo Derecho. Desde el resurgir de los ordenamientos jurídicos que forman el Ius Commune, momento en que se tiene conciencia de la aplicación del derecho justinianeo y del derecho canónico, los obispos y abades hacen los esfuerzos económicos precisos para dotar a los fondos bibliográficos de sus respectivas instituciones de todo aquel material literario que sea de aplicación al nuevo momento jurídico.

Las bibliotecas de las principales catedrales y monasterios se poblarán, amén de algunas copias de manuscritos de textos del derecho propio castellano, de un nutrido volumen de textos jurídicos romanos $\mathrm{y}$ canónicos, así como de los principales aparatos de glosas y comentarios a los mismos. Los testimonios de Villa-Amil y Castro siguen siendo de indiscutible valor a los efectos de precisar la composición de esas bibliotecas que alumbran en su interior el conocimiento de una nueva ciencia, de un nuevo saber especializado y culto $^{45}$. La labor de forma-

${ }^{45}$ Cfr. VILLA-AMIL Y CASTRO, J., Los códices de las iglesias de Galicia en la Edad Media. Imprenta de Aribau, Madrid, 1874, pp. 81-127. El estudio del polígrafo gallego se ha centrado, sobre todo, en las bibliotecas de las catedrales de Santiago y de Lugo, a lo largo de los siglos XIII y XIV. Es lícito pensar que el resto de las catedrales gallegas dispusiesen de una riqueza bibliográfica análoga y que lo mismo acontecería con aquellos monasterios dotados de mayor riqueza. Entre los textos que cita VillaAmil, han de mencionarse los siguientes: por lo que respecta al derecho civil, el Digesto Viejo, con y sin apparatum, las Instituciones de Justiniano con la Glosa Ordinaria de Accursio, y el Código, con y sin el aparato glosador. En el campo del derecho canónico, aparecerán las dos obras más relevantes del derecho de la Iglesia: el Decreto de Graciano y las Decretales de Gregorio IX con los comentarios de Juan Andrés. Entre las obras doctrinales, se citan las que siguen: el Apparatus Bernardi, sobre las Decretales, obra de Bernardo Compostelano; la Summa de Bonaguide Aretino; el tratado Casus Priorum Decretalium, atribuido a Bernardo; las Caullationes de Juan de Deo; varias obras de Egidio de Fuscoris; las Quaestiones de Bartolomé de Brescia; las Quaestiones de Rofredo Butiense; la Summa Damasi super Decretalibus; la Summa de Godofredo de Trani; y la Summa Magistri Iohannes super Decreto, atribuida a Juan de Semaca. Mayor información sobre el particular, vid. GARCÍA Y GARCÍA, A., «El derecho común medieval en las bibliotecas de Galicia», en Glossae. Revista de Historia del Derecho Europeo, 1 (1988), pp. 189-198. 
ción de esos santuarios del saber jurídico se completaría con las donaciones y legados de los canónigos a las catedrales de nuevos libros de su propiedad ${ }^{46}$. Numerosos testamentos de los siglos XIII y XIV hacen precisas referencias a esta ingente cantidad de libros jurídicos que se traslada desde los canónigos a las sedes catedralicias ${ }^{47}$ y no solamente Santiago de Compostela parece ser la destinataria de tales documentos y

${ }^{46}$ Cfr. VILLA-AMIL Y CASTRO, J., Los códices de las iglesias de Galicia en la Edad Media, pp. 20 y ss. Entre los varios ejemplos que se señalan, hay que destacar el testamento de Gonzalo Pérez en el que se citan ejemplares del Decreto, Séptima Partida, Ordenamiento de Alcalá, Fuero Juzgo, el Speculum de Belovacense, el Speculum de Guillermo Durando, y la Compilación de Inocencio III (Año 1381, pp. 20-21); la fundación de un aniversario que grava un ejemplar del Decreto y otro de las Decretales hecho por el arcediano Pedro Arias (Año 1230, p. 40); el legado del arcediano Fernando Martínez hecho a favor de la catedral de Santiago, cuyo objeto es el «decretum, Liber Inocenti, Apostillas, casus decreti, summa fuscari» (Siglo XIII, p. 41); o la cesión al cabildo hecha por el arcediano Miguel de «quoddam digestum vetus et quoddam codicem et quandam institutam cum glosa ordinaria (Siglo XIV, p. 45). Más referencias al Decreto y a las Decretales, en pp. 46-47 y pp. 48-52, y a los textos justinianeos, en p. 52 y p. 55.

${ }^{47}$ LÓPEZ FERREIRO, A. (dir.), Colección diplomática de Galicia Histórica. Edición facsimilar. Edicións do Cerne, Santiago de Compostela, 1998, doc. $\mathrm{n}^{\circ}$. XXXVI, p. 179. Año 1232. Testamento del arcediano don Abril Fernández: «Mando domino meo compost Archiepiscopo omnes libros meos quos de me tenet in pignore Simon framench apud parisius si eos uoluerit de pignore extrahere. Sin autem, mando eos capitulo si capitulum extrahere illos uoluerit et si dns Archidiaconus (Archiepiscopus) uel capitulum eos extraxerit semper sint ad comodum et seruitium Ecclesie compostelane»; doc. $\mathbf{n}^{\mathbf{0}}$. XXXIX, p. 185. Año 1269. Testamento del canónigo don Abril Fernández: «C. It Martino martinii clerico consanguineo meo sls $\mathrm{CC}$ et summam meam de gaufrido. It lego aprilis iohannis consanguineo meo librum meum codicem de legibus»; doc. $\mathrm{n}^{\circ}$. XL, p. 189. Año 1270. Testamente de don Pelayo Eans: «Mando Benedicto martini canonico quiniones quos habeo in Ecclesiis de luou et de Raariz quod teneat eos in uita sua et post mortem suam dimittat eos clerico propinquiori de genere Magistri Pichote, et mando ei digestum uetus quod fuit Cardin Martini pelagiz et Summa Causidi et sls CC.- Mando Petro martini consanguineo meo decretales meas nouas et sls mille alfonsinorum»; doc. $\mathrm{n}^{\circ}$. LIV, $\mathrm{p}$. 244. Año 1276. Testamento de don Nuño Fernández: «It lego decretum meum fernando Roderici canonico. It libros meos legales lego dicto fernando Roderici et Johanni petri canonicis et nepotibus meis et ad mortem alterius remaneant superstiti quo defuncto tam decretum quam libri legales ad capitulum deuoluantur»; doc. $n^{\circ}$. LV, p. 253. Año 1283. Testamento de don Alonso Pérez: «It mando quod soprinus meus Bernardus Martini clericus habeat quitas et liberas decretales meas quas sibi acomodaueram per placitum et faciar de eis uelle suum».

«CUADERNOS DE ESTUDIOS GALLEGOS», Tomo XLVIII, Fascículo 114, Santiago 2001. 
manuscritos: Mondoñedo ${ }^{48}$ u Orense ${ }^{49}$ contaron con importantes textos y tratados sobre las materias civiles y canónicas más relevantes.

Pero la presencia de todo este caudal bibliográfico, que se extiende hasta la finalización de la Baja Edad Media ${ }^{50}$, obedece a un proceso edu-

\footnotetext{
${ }^{48}$ Por ejemplo, la catedral de Mondoñedo es asimismo depositaria de algunos manuscritos de incalculable valor. Vid. CAL PARDO, E., Catálogo de los documentos medievales escritos en pergamino del Archivo de la Catedral de Mondoñedo (871-1492). Servicio de Publicaciones de la Excma. Diputación Provincial de Lugo, Lugo, 1990, doc. $n^{\circ}$. 646, p. 276. Año 1316: «Domingo Eanes y Pedro Fernández, racioneros de la Catedral de Monsoñedo, hicieron entrega, por ante el Obispo D. Rodrigo, el Deán y varios canónigos, de varios objetos, que debían ser custodiados por el cabildo: un Breviario, un Libro de Sentencias (...) un Digesto viejo, una Suma de Egidio Fuscariis (...)»; doc. $n^{\circ}$. 759, pp. 306-307. Año 1328: «Cosas de la Capilla del Obispo D. Gonzalo, que también fueron entregadas al Obispo don Juan (...) Un ordinario. Varios libros del Nuevo y Antiguo Testamento. Los Morales de Job; un Breviario, que había sido del Obispo D. Nuño. Salterio. Libro Juzgo. Un Digesto viejo»; doc. $n^{\circ}$. 854, p. 333. Año 1336: «Los canónigos, reunidos en Cabildo, dieron al Arcediano de Vivero el libro Iulgo, que les había legado su hermano D. Diego Pérez (...)»; doc. n. 912, pp. 350-351. Año 1348: «Dejó asimismo al Cabildo su Speculum de Derecho que había comprado en la Corte de Roma, el que deberían vender y emplear su producto en lo que fuere más conveniente para la Iglesia»; doc. $n^{\circ} .1 .076$, p. 405. Año 1384: «Estando los canónigos de Mondoñedo en el Coro de la Catedral, se presentó Lopo Méndez, escudero del Obispo D. Francisco, que se obligó a entregar al Cabildo unas Decretales que estaban en Salamanca, en el plazo de un año, a partir de 8 de septiembre, o a dar, en su lugar, 800 maravedís, de a diez dineros novees cada uno. Las Decretales de referencia estaban en poder de Gonzalo Vermues, sobrino de dicho Lopo Meendez, las cuales prestó Juan de Sayoane, que las tenía recibidas del Cabildo».

${ }^{49}$ Vid. DURO PEÑA, E., «Los códices de la catedral de Orense», en Hispania Sacra. Revista de Historia Eclesiástica, vol. XIV (1961), pp. 185-212. De entre los manuscritos más importantes, datados alrededor de los siglos XIII y XIV, deben destacarse las Compilaciones antiguas, con la sola excepción de la quinta, con todo su aparato de glosas (la I con las glosas de Alano, Lorenzo, Vicente y Tancredo; la II con las de Tancredo, Lorenzo y Alberto; la III con las de Juan Teutónico, Vicente y Lorenzo; y la IV con las de Juan Teutónico) y las colecciones de Decretales de Gregorio IX y Bonifacio VIII, así como el Speculum Iudiciale y la Summa de Monaldo, ambos del siglo XIV. Fragmentos de códices de las mismas centurias nos refieren la existencia en la catedral orensana de más manuscritos de las Decretales, las Compilaciones antiguas, las Partidas e incluso de la Hispana.

${ }^{50}$ Vid. LÓPEZ FERREIRO, A., Galicia en el último tercio del siglo XV. Andrés Martínez Editor, La Coruña, 1897. Tomo II, pp. 211-241; y ESCOLAR SOBRINO, H., «Libros y bibliotecas en la Baja Edad Media», en La enseñanza en la Edad Media, ed. cit., pp. 269-302. Ya en la época moderna es destacable la presencia de librerías bastante completas en relación al mundo del derecho. Un ejemplo puede ser la de Geraldo del Sol, librero de la ciudad de Santiago, cuyo inventario data del año 1553, en LÓPEZ FERREIRO, A. (dir.), Colección diplomática de Galicia Histórica, ed. cit., doc. $\mathrm{n}^{\mathrm{o}}$. LVI, pp. 255-261.
} 
cativo que se ha dado en Galicia. Evidentemente, la aparición de esas bibliotecas viene motivada por la existencia de una serie de personas, generalmente eclesiásticos, que necesitan esos libros y los van a emplear de forma usual en sus actividades cotidianas. Eclesiásticos que en buena parte se han formado en universidades europeas y que de vuelta a sus patrias han servido como vehículos transmisores de la nueva cultura jurídica que se está forjando desde Italia hacia el resto del Occidente europeo, ya como docentes, ya como operadores jurídicos (jueces, escribanos, abogados, etc.). Nos estamos refiriendo a juristas de la talla de Martín Arias, Bernardo Compostelano Antiguo, Bernardo Compostelano el Joven o Juan Hispano ${ }^{51}$. Esos estudios, en fin, han de obedecer a una cultura y a unos conocimientos previamente asimilados, que nos ponen sobre la pista de, acaso, uno de los más importantes centros de estudios de todo el Alto Medievo español: la Escuela Catedralicia de Santiago de Compostela. De hecho, Eduardo de Hinojosa llega a calificar a Santiago de Compostela como la «ciudad que durante los siglos XII y XIII fue el principal emporio de erudición civil y canónica en nuestra península $)^{52}$, si bien no parece que fuera el único centro relevante de Galicia ${ }^{53}$. La idea de Koschaker de que el Derecho Común era un derecho de juristas, esto es, de especialistas formados plenamente en el conocimiento de todos los resquicios de la ciencia jurídica, determina el papel relevante que las escuelas, prima-

\footnotetext{
${ }^{51}$ Vid. sobre estos juristas de origen gallego y de otros autores de procedencia hispana, GARCÍA Y GARCÍA, A., «La canonística ibérica (1150-1250) en la investigación reciente», en El Derecho Común en España. Los juristas y sus obras. Universidad de Murcia, Murcia, 1991, pp. 47-77. Mayores precisiones sobre los de raigambre gallega, vid. del mismo, «Canonistas gallegos medievales», en Compostellanum, vol. XVI, 1-4 (enero-diciembre 1971), pp. 101-124; y «Presencia e influjo de los canonistas gallegos», en La canonística medieval en Galicia. Collectanea Scientifica Compostellana, I. Instituto Teológico Compostelano, Santiago de Compostela, 1981, pp. 10-37. Breves consideraciones sobre aquellos en GIBERT SÁNCHEZ DE LA VEGA, R., Ciencia jurídica española. Imprenta de Francisco Román, Granada, 1983, pp. 2-3.

${ }^{52}$ Cfr. HINOJOSA Y NAVEROS, E. de, «La recepción y el estudio del derecho romano en España», en Obras, ed. cit. Tomo III, pp. 322-324.

${ }^{53}$ Es muy probable que otras catedrales organizasen, a causa de lo impuesto en algunos cánones conciliares, instituciones educativas similares, de las que da cuenta, a modo de ejemplo, GARCÍA CONDE, A., "La escuela catedralicia de Lugo», en Boletín de la Comisión Provincial de Monumentos Históricos y Artísticos de Lugo. Tomo III, 29-30 (1947), pp. 214-227.
} 
rios embriones educativos, y luego las universidades, tuviesen un protagonismo indiscutible ${ }^{54}$.

La existencia de esa escuela catedralicia nos pone sobre la pista clara de una institución erigida por y para la Iglesia, cuyo objetivo fundamental sería la formación de los propios clérigos y canónigos ${ }^{55}$. Diferentes pasajes de la conocida Historia Compostelana aluden de forma velada a la posible educación de estos y al papel capital que desempeñó el principal artífice de aquella crónica, Diego Gelmírez $z^{56}$. La situación que presentaba la educación de los clérigos compostelanos, descrita con palabras bastante críticas en la Historia, explica el proceso de reforma docente que impulsa el prelado jacobeo ${ }^{57}$, quien empleando el arado de la disciplina convirtió a los antiguos clérigos en personajes relevantes y

${ }^{54}$ Vid. RÁBADE OBRADÓ, M. P., Las universidades en la Edad Media. Arco/Libros, S.L., Madrid, 1996, con la bibliografía citada en pp. 61-62. Sobre las escuelas de derecho, vid. GARCÍA Y GARCÍA, A., «Las facultades de leyes» y «La enseñanza del derecho en la Universidad medieval», ambos artículos recogidos en el volumen En el entorno del Derecho Común, pp. 73-92 y pp. 93-117, respectivamente.

${ }^{55}$ Estudiada por DÍAZ Y DÍAZ, M. C., «Problemas de la cultura en los siglos XI-XII. La escuela episcopal de Santiago», en Compostellanum, vol. XIV, 1-4 (1971), pp. 187200; y «La escuela episcopal de Santiago en los siglos XI-XII», en Liceo Franciscano. ${ }^{\mathrm{a}}$ época. Año XXVIII, 82-84 (enero-diciembre, 1975), pp. 183-188; y SANTIAGO-OTERO, H., «La Escuela Catedralicia de Santiago de Compostela, siglos XI-XII», en MENDES ALMEIDA, J. y PINTO REMA, H. (eds.), Fraternidade e abnegação. A Joaquim Verissimo Serrão. Acadèmia Portuguesa da Història, Lisboa, 1999. Tomo I, pp. 557-569.

${ }^{56}$ Él mismo poseedor de una destacada biblioteca con algunos textos jurídicos de relevancia, siguiendo la opinión de GARCÍA Y GARCÍA, A. «Del derecho canónico visigodo al derecho común medieval», en Iglesia, Sociedad y Derecho. Bibliotheca Salmanticensis. Estudios, 74, Salamanca, 1985, pp. 32-34 y pp. 42-43; y «De las colecciones gregorianas al derecho común medieval en Compostela», en Estudios de Historia del Derecho Europeo. Homenaje al prof. Gonzalo Martínez Díez. Universidad Complutense, Madrid, 1994. Volumen III, pp. 39-46.

${ }^{57}$ Historia Compostelana, sive de rebus gestis D. Didaci Gelmirez, primi compostellani archiepiscopi. Edición de E. Flórez, en España Sagrada. Theatro geographico-historico de la Iglesia de España. Imprenta de la viuda e hijo de Marin, Madrid, 1791. Tomo XX. Libro I, Capítulo III, 2, ff. 18-19: «Canonici itaque hujus Ecclesiae, qui dispensatores Ecclesiasticae dignitatis esse deberent, ad tantum inopiae tum temporis devenerunt, quod paupertatis vinculis obligati, cibis corporeae sustentationis in ipsa etiam Canonica modis omnibus indiguerunt. Quod autem valde indignum est, ac flebiliter condolendum, vilissimis etiam \& variis vestimentis induti, quasi totius doctrinae Ecclesiasticae consuetudinis expertes in choro laudes Deo inordinate cantabat». 
cultivados $^{58}$, como acontece con Hugo o con Munio, ascendidos a importantes episcopados, de los cuales se destaca el hecho de que fueran educados en el seno de la Escuela compostelana: «Quoniam B. Jacobo Ecclesie suae filios exaltari placuit, duo Canonicis, quos supradictus Episcopus educaverant $\rangle^{59}$. La presencia de maestros extranjeros formando parte de la comitiva del prelado que acude al concilio de Auvernia ${ }^{60} \mathrm{o}$ incluso la marcha de algún familiar a estudiar en los estudios generales de otros reinos $^{61}$, se convierten en manifestaciones sintomáticas de los nuevos aires que se expanden por el Occidente peninsular, en concordancia con lo que acontecía en el resto de Europa. Gelmírez reorganiza, pues, la formación del cabildo, dándole nuevos bríos y nueva orientación ${ }^{62}$. De esa re-

${ }^{58}$ Historia Compostelana, ed. cit. Libro I, Capítulo LXXXI, 1, f. 144: «Postquam enim ad Pontificatus honorem, annuente Deo, in Ecclesia supradicti Apostoli sublimatus est, Clericos ibi degentes tamquam bruta animalia vomere disciplinae excoluit, honestate morum ornavit, jugali asperitate depressos, Scholarum studio desudare compulit. Praeterea non solum illos ad ignorantiae tenebris extraxit, verumetiam unumquemque prout merebatur, ad honoris fastigium sublimando Ecclesiasticis facultatibus ubertim ditavit. Quid plura? Supradictus paterfamilias vineam sibi traditam prudenter excoluit: \& de commissi talentis Domino suo lucrum reportare curavit».

${ }^{59}$ Historia Compostelana, ed. cit. Libro I, Capítulo LXXXI, 2, ff. 144-145.

${ }^{60} \mathrm{Al}$ referir los acompañantes de Gelmírez, se hace mención expresa a las siguientes personas, en Historia Compostelana, ed. cit. Libro II, Capítulo VIII, 1, ff. 268-269: «Hi sunt Canonici qui cum Episcopo ad Concilium Alverniae vestibus atque divitiis pollentes, ceterisque quae tanto itineri tantoque negotio necessaria erant abundantes, viae destinantur: videlicet D. Auriensis Episcopus, Canonicus noster, Petrus Gundesindides Cardinalis \& primiclerus, P. Cresconides Archidiaconus B. Thesaurarius, \& frater ejus P. Stephanides M. frater D. Auriensis Episcopi, \& ego Girardus. Nobiscum quoque qui non erant Canonici, scilicet Magister Raucelinus, Robertus Salernitanus Medicus, \& ceteri Clerici cum sua turba militum atque clientum».

${ }^{61}$ Es el caso del sobrino de Gelmírez, del que se dice en Historia Compostelana, ed. cit. Libro II, Capítulo XLIX, 1, f. 346, que «in Francia philosophicam disciplinam adiscebat (...) Qui assumptis secum quibusdam Canonicis, qui secum studium frequentabant, venti Cluniacum».

${ }^{62}$ Historia Compostelana, ed. cit. Libro I, Capítulo XX, 3, ff. 55-56; Libro II, Capítulo II, ff. 254-255, sobre la propia formación de Gelmírez. Muy especialmente, Libro III, Capítulo XXXVI, ff. 543-544, donde se narra la actuación de los prelados precedentes y el gran cambio que supuso la llegada de Gelmírez en el orden formativo de los canónigos: «Postea vero Domnus Didacus ejusdem Sedis primus Archiepiscopus LXXII. Canonicos literarum studiis eruditos, Ecclesiastici officii peritos, vita \& moribus ornatos, Ecclesiae servitio in perpetuum mancipavit, communesque redditus unde victum \& vestitum sufficienter $\&$ honorifice haberent in eorum potestate $\&$ providentia permisit».

«CUADERNOS DE ESTUDIOS GALLEGOS», Tomo XLVIII, Fascículo 114, Santiago 2001. 
forma nacerán importantes figuras de la canonística medieval hispana, porque había un importante sustrato educativo, y se formará una escuela donde se eduquen los que luego ejercerán los principales cargos y oficios de tipo jurídico, como notarios o jueces.

De hecho, el mismo texto manejado nos proporciona mayores datos sobre la presencia en la sede compostelana de noticias reveladoras de la auténtica vigorización cultural que el pontificado de Gelmírez supuso. Los concilios provinciales celebrados en Compostela en los año 1060 y 1063, ordenaban que toda iglesia estableciera escuelas. Sin embargo y a pesar de tales indicaciones, parece que la enseñanza estaba reducida a unos rudimentos de cuestiones religiosas y a la Gramática. Gelmírez, conforme al testimonio de la Historia Compostelana, completa la escuela episcopal jacobea con un maestro de Lógica y Oratoria ${ }^{63}$, incorporando asimismo a un médico de Salerno, llamado Roberto ${ }^{64}$. Siguiendo la opinión de López Ferreiro, ese maestro de Lógica y Oratoria bien pudo ser Raucelino, citado entre los miembros de la comitiva que acompaña al prelado a Francia ${ }^{65}$, o bien Giraldo, uno de los redactores de la propia Historia Compostelana ${ }^{66}$.

Conforme a otro testimonio del mismo López Ferreiro, es más que factible la presencia en la ciudad jacobea del maestro Rainerio de Pistoya, llamado por el prelado para ocupar la dignidad de Maestrescuela y a quien el mismo autor que seguimos atribuye la redacción de los últimos capítu-

\footnotetext{
Al mismo cambio alude el Liber Sancti Jacobi. Codex Calixtinus. Traducción de A. Moralejo, C. Torres y J. Feo. C.S.I.C. Instituto Padre Sarmiento de Estudios Gallegos, Santiago de Compostela, 1951. Libro V, Capítulo X, pp. 572-573.

${ }^{63}$ Historia Compostelana, ed. cit. Libro I, Capítulo XX, 3, f. 55: «De cetero non solum Clericos, qui propter inopiam victus, quem de redditibus Ecclesiae usque ad medium anni habere vix poterant, propriam Ecclesiam dimisserant, verum etiam alios e diversis partibus colligens, locato de doctrina eloquentiae Magistro, \& de ea quae discernendi facultatem plenius administrat, ut nos ab infantiae subtraheret rudimentis, suo nos commendavit imperio».

${ }^{64}$ Historia Compostelana, ed. cit. Libro II, Capítulo VIII, 1, f. 269.

${ }^{65}$ Historia Compostelana, ed. cit. Libro II, Capítulo VIII, 1, f. 269.

${ }^{66}$ Cfr. LÓPEZ FERREIRO, A., Historia de la Santa A. M. Iglesia de Santiago de Compostela. Imprenta del Seminario Conciliar, Santiago de Compostela, 1900. Tomo III, pp. 255-256.
} 
los de la Historia Compostelana ${ }^{67}$. Algunos documentos aislados hacen referencia a esa formación ultrapirenaica de los canónigos compostelanos: Nuño Fernández, canónigo de la catedral, «iturus parisis more scolastico ${ }^{68}$, o en el testamento del arcediano Abril Fernández, del año 1232 , quien concede al arzobispo compostelano en una de sus mandas «omnes libros meos quos de me tenet in pignore Simon framench apud parisius si eos uoluerint de pignore extrahere ${ }^{69}$. La escuela se hallaría, de creer el testimonio que proporciona Aymeric Picaud, entre la catedral y el palacio episcopal ${ }^{70}$.

Las conexiones del prelado compostelano no dejan de sorprender: el cardenal Gregorio, autor de una de las más importantes recopilaciones de derecho canónico previas al Decretum de Graciano, dedica a Diego Gelmírez su obra conocida como Policarpus ${ }^{71}$.

${ }^{67}$ Cfr. LÓPEZ FERREIRO, A. Historia de la Santa A. M. Iglesia de Santiago de Compostela. Imprenta del Seminario Conciliar, Santiago de Compostela, 1901. Tomo IV, p. 172.

${ }^{68}$ MOURIÑO SERANTES, M., El Tumbo $C$ de la Catedral de Santiago. Tesina de Licenciatura. Facultad de Filosofía y Letras, Santiago de Compostela, 1967, doc. $n^{\circ} .3$. Año 1174.

${ }^{69}$ LÓPEZ FERREIRO, A. (dir.), Colección diplomática de Galicia Histórica, ed. cit., doc. $\mathrm{n}^{\circ}$. XXXVI, p. 179.

${ }^{70}$ Liber Sancti Jacobi. Codex Calixtinus, ed. cit. Libro V, Capítulo IX, pp. 556-557: «De los pórticos. Esta iglesia tiene tres pórticos principales y siete pequeños (...) y el séptimo de la Escuela de Gramáticos que también ofrece acceso al palacio arzobispal».

${ }^{71}$ LÓPEZ FERREIRO, A., Historia de la Santa A. M. Iglesia de Santiago de Compostela. Tomo III. Apéndice, doc. $\mathrm{n}^{\circ}$. XXIX, pp. 83-85: «Incipit prologus Gregorii cardinalis presbyteri tituli S. Grysogoni ad Didacum ecclesie S. Iacobi episcopum. Dilecto domino Didaco S. Iacobi ecclesie pontificali infula digne decorato Gregorius presbyterorum humilimus salutem. Petistis iamdundum et hoc sepe, ut opus arduum et supra vires meas aggrederer, Librum canonicum scilicet ex romanorum pontificum decretis, aliorumque sanctorum patrum auctoritatibus, atque diuersis conciliis autenticis utiliora sumens; sediatim componerem. Id uero non iccirco a me inscio placuit requirere, ut, aut uestra excellens sapientia huic labori, uel quam multo grauiori non sufficeret, aut plures ad hoc magis idoneos ac prudentiores uoluntariae obsecundari preceptioni due non haberet, sed ut in hoc magno diu exercitatus ad alia maiora iniuncta instructio et paratio efficerer, seu etiam si in aliquo prauitas ingenii mei deficeret, prudentia uestra michi magistra, et auxiliatrix manus extenderet. Cui inquisitioni, etsi altius ingenium expeteret et meis uiribus minime conueniret, et, ne temerarium a quibusdam iudicaretur, timerem, tamen, ne tantum ac talem uirum recusatione offenderem,acquieui. Atque tandem hac maxime fiducia, ut uestra aucthoritate interposita a detrahentium morsibus defenderer, uestre iussioni parui. Sicut enim olim in ecclesia, et quotidie negociis negocia uarie succedunt, atque multarum 
La semilla plantada por el prelado da sus frutos en los años siguientes, cuando nos encontramos ante un detallado estatuto del cabildo catedralicio pensado para aquellos de sus miembros que se dedicasen al estudio, del año 1169 , que lleva la rúbrica del arzobispo Pedro II. Se trata de un elenco de medidas económicas dirigidas a proporcionar el sustento necesario con el fin de impedir que alguno de los beneficiados catedralicios pudiese dejar los estudios que hubiera iniciado, incluso los que los cursasen fuera de Galicia, por causa de pobreza ${ }^{72}$. En una constitución del año siguiente,

causarum pro temporis euentu actiones succrescunt, sic sub titulis unicuique congruentia capitula auctorum tempore perspecto plurima connexui, et octo librorum distinctionibus uolumini compendiose finem imposui. Cui ex ratione compositionis a nominis aucthoritate sumpta Policarpus nomen conuenienter indidi. Quod uestram obnixe deprecor industriam, ut compositionem et compositum perpiciat atque perspiciendo si quid deesse, si quid uero magis quam deceat cognouerit, cauta consideratione, quod decens est compleat, quodque indecens est, remoueat. Approbandum uero ad laudem uestram, et ad obedientiam uestre iusssionis augendam moderatione habita comprobor. Preterea ne per libri seriem lectoris rei indistinctam turbaret, hujus operis titulos preponere placuit, ut suis locis exigere possit, quod sub numero competenti predictum esse cognoscit».

${ }^{72}$ LÓPEZ FERREIRO, A., Historia de la Santa A. M. Iglesia de Santiago de Compostela. Tomo IV. Apéndice, doc. $\mathrm{n}^{\circ}$. XL, pp. 99-101: «Ecclesiastici maiestati uiris ecclesiasticisi inuigilare quanto magis este necessarium, tanto deuotius insistendum. Et quoniam Ecclesie status per litteratos et sapientes qui bonis moribus luceant, obtime conseruatur dignum est. In quantum possibilitatis patitur nonnullas que studiosis et liberalibus Ecclesiarum filiis neccesitates aduersantur, auerti. Sunt enim plures qui licet studendo propositum integro animo gerunt, tamen paupertatis mole depressi id ad quod spirant aspirare non possunt. Inde fit ut nonnunquam uirtutis intentio langueat ubi nouerca liberalitatis inopia exercitium uetat. Eapropter nos Ecclesie compostellane Canonici plena cum deuotione de statu nostro deliberantes disciplinam colendam Judicauimus nostrisque fratribus qui studia bonarum artium uellent amplecti de comuni nostro sine grauamine prouidere studuimus. Impetrato itaque liberali ac deuoto assensu pii Patris nostri archiepi. Petri secundi. Statuimus pariter et scripture testimonio decreuimus confirmandum ut clerici de canonica nostra nostrates et Ecclesie nostre mansionarii ad studium litterarum anelantes dum iuxta terminum sibi a capitulo constitutum in literature studiis honestes manserint ubicumque de mense nostre denariis quos de honore altaris tantummodo ad uitum comunem constiterit pertinere equalem semper cum aliis in Ecclesia manentibus percipiant per suos uicarios portionem, quatinus ex parte uicta inopia ad colendam disciplinam promptiores intendant et tamquam in felicem embolam missi uirtutis cultum moribus expeditis excipiant. Sic enim Ecclesia nostra in melius crescens tanquam mater de filio sapiente letabitus et cum boni heredes successerint: integritatis sue non mutilabitur status. Atque hoc solummodo de mansionariis nostris qui nobiscum portare solent pondus diei et estus dum pro facto isto nec ecclesiae uel nobis detrimentum neque quod modicum omnibus uitandum est cum emerserit scandalum sub hac prouida et salubri 
se detallan las funciones que debía desarrollar el Maestrescuela catedralicio $^{73}$, síntoma de la consolidación de la institución académica, quien además de fijar la duración y calidad de las lecciones de Maitines, ha de buscar y establecer en la ciudad un maestro de Gramática, el cual tendrá como misiones principales enseñar a los clérigos adscritos a la catedral y a los niños que sirviesen en aquélla, además de a todos los que lo deseen de la ciudad o de la misma diócesis, y, por otro lado, observar cómo se desarrollan las lecturas en el coro, corregir la pronunciación y la entonación, y redactar las cartas latinas del cabildo ${ }^{74}$.

contemplatione decernimus obseruandum. Nan quicumque alius uel grauitate potentie sue uel generis elatione seu per alicuius potentis preces porrectas seu per cauillationem aliquam super hac dispensatione littigans tam legitimam et neccesariam institutionem perturbare attemptauerit uidelicet ut sicut unus de mansionariis nostris predictam gratiam misericordie et honestatis impensam sibi usurpare non minus imprudenter quam impudenter contendat, a societate nostra alienum et Ecclesie nostre benefficio omnino priuatum se sentiat. Insuper etiam excellentis dni nri Petri archiepi auctoritate et confirmatione excommunicatum sese congnoscat. Si qui uero de nostris quod absit uoluntate laxius discurrendi ymaginariam studenti occasionem pretenderint, quam cito auditi fuerint minus honeste in absentia conuersari, per litteras capituli a studio simulato reuocandos censemus et si ad primam uocationem redire distulerint statim predicto priuandos iudicamus benefficio quousque de eis iuridica relatione honestam uitam et ad studendum solicitam intentionem cognoscamus. Vtque hoc nostrum sine liuoris macula statutum perpetuo robore maneat inconuulsum, scripti presentis paginam subscriptionibus propriis in testimonium obseruationis communimus. Facta scripture serie III kls ausgusti. Sub Era M. CC: VII per eminentem auctoritatem et confirmationem benigni patris nostri Archiepiscopi dni. Petri secundi».

${ }^{73}$ Cuyas funciones se referían, más que a la educación directa de los canónigos, a la búsqueda y selección de los maestros de los futuros miembros del coro catedralicio, de acuerdo con el parecer de PÉREZ RODRÍGUEZ, F. J., La Iglesia de Santiago de Compostela en la Edad Media: el Cabildo Catedralicio (1110-1400). Xunta de Galicia, Santiago de Compostela, 1996, pp. 69-70. Aparece, pues, más como un buscador y un corrector, pero sin una intervención directa clara y decidida en la educación.

${ }^{74}$ LÓPEZ FERREIRO, A., Historia de la Santa A. M. Iglesia de Santiago de Compostela, ed. cit. Tomo IV. Apéndice, doc. $\mathrm{n}^{\circ}$. XLII, pp. 105-106: «Cum comuni utilitati et maxime neccessarie insistendum sit potius quam priuate. Ea propter Nos Ecclesie compostellane canonici plena cum deliberatione prouide studuimus habere sigilum comne interuiniente assensu pii Patris archiepi dni Petri. Statuentes pariter et scripture testimonio confirmantes ut de cetero. Magisterscolarum qui est et deinceps pro tempore fuerit, illud teneat et penes se habeat nomine capituli compostellani fideliter conseruandum qui in creatione sua ad sca dei euangelia juramentum prestet illud fideliter conseruare et in custodiendo diligentiam adhibere et litteras capitulum summo Pontifice seu Regibus 
Casi un siglo después, el protagonismo creciente de lo jurídico halla su mejor ejemplo en la biblioteca del arzobispo Bernardo II: su contenido es esencialmente litúrgico y teológico, en la línea de las clásicas bibliotecas medievales. Sin embargo, se puede apreciar la presencia de los más señeros textos legales del derecho romano y del derecho canónico, así como las glosas y comentarios de los más relevantes juristas del momento. El prelado muere en 1240, pero el inventario es de 1236: figuran allí los tres Digestos, el Código, las Sumas de Azzo, Decreto de Graciano, textos de Huguccio de Pisa, la tercera y la cuarta de las «Compilaciones Antiguas», entre otras muchas ${ }^{75}$.

\begin{abstract}
destinauerit pro comuni utilitate Ecclesie non deferat sigillare et sic in omnibus aliis negociis que utilitatem Ecclesie sortiantur non obstante contraditione etiam alicuius seu aliquorum qui circa talia quandoque maliciam seu uoluntatem potius quam utilitatem Ecclesie amplectuntur. In aliis uero negotiis comunibus seu priuatis que neccessaria non sunt ipsi Ecclesie seu mense comuni set de gratia, littera impetrata uno de fratribus contradicente non sigilletur. Verum si predictum magistrum scolarum abesse contigerit idem in Capitulo de assensu et uoluntate Capituli illud comittat alicui de colegio fide digno quousque ad suam Ecclesiam reuertatur qui sustitutus eidem magistro scolarum et Capitulo juramentum prestet illud fideliter conseruare et ad mandatum Capituli litteras sigillare ut est superius annotatum. Magisterscolarum preterea debet per se uel per alium taxare cotidie lectiones ad matutinas et ponere magistrum in ciuitate in facultate gramatice qui socios Ecclesie clericos et pueros corrigat ac alios ciuitatis et diocesis doceat et instruat fideliter in eadem et qui ad nutum Magistriscolarum omnes litteras Capituli dirigat et componat cui propter laborem in apertura arche operis festo pasche et in denariis de altari ad uitum et uestitum asignatis nobis et nostre mense, damus annuatim LX solidos legionenses tertiam partem predicte pecunie quam percipiat de oblationibus ipsius arche et reliquas duas partes de altari in parte nostra et iste debet uenire in omnibus festiuitatibus ad seruiendum choro et legentes ibidem corrigere in sillabis et acentu. Propter que omnia adimplenda dicto Magistro scolarum de nostra canonica portionem duplicatam ut habeat perpetuo asignamus qui si negligens in predictis fuerit seu remisus duplicata careat portione ratione cuius tenetur Capitulo Clericum idoneum presentare qui coro die noctuque seruiat in diuinis et ex tunc iste talis duplarius nuncupetur qui in choro et processionibus post minores portionarios qui maniapanes uulgariter nuncupantur incedat et cum eis officiet in festis de duabus capis qui in pane portionis per Decanum si deffecerint puniantur. Actum in Capitulo in Quintana palatii present et consentiente humili patre nostro predicto Archiepiscopo. VIII kls. Ausgusti. Era M. CC. VIII».

${ }^{75}$ Vid. VÁZQUEZ JANEIRO, I. y GARCÍA Y GARCÍA, A., «La biblioteca del arzobispo de Santiago de Compostela Bernardo II (m. 1240)», en Antonianum, 61 (1986), pp. 540-568. De nuevo se ocupa de este tema el segundo de los autores citados en su estudio «De las colecciones gregorianas al derecho común medieval en Compostela», en Estudios de Historia del Derecho Europeo, ed. cit. Volumen III, pp. 39-46.
\end{abstract}

«CUADERNOS DE ESTUDIOS GALLEGOS», Tomo XLVIII, Fascículo 114, Santiago 2001. 
A partir de todo este caldo de cultivo educativo, era lógico pensar en que las manifestaciones del nuevo derecho no tardarían en aflorar. Y era lógico además que aquel texto castellano en el que se fue insertando el Derecho Común, las Partidas atribuidas a Alfonso X, enciclopedia jurídica que combina algunos aspectos del derecho del reino con lo más granado de la tradición romano-canónica, a nivel legal y doctrinal, tuviese su reflejo en la lengua vernácula de la propia región gallega. Insistimos así en una línea de pensamiento ya esbozada cuando se habló de las versiones y referencias al derecho visigodo: en una época de cultura tan poco dinámica y tan poco comunicada, solamente se copia y se traduce lo que se necesita, lo que se emplea o interesa que se emplee. Las versiones en gallego de las Partidas, desgraciadamente hoy perdidas, dan buena prueba de ese proceso y permiten deducir la necesidad de esos textos para efectuar una cabal aplicación del derecho por parte de los principales operadores jurídicos, además de acercarlo a la lengua que el pueblo comenzaba a hablar ${ }^{76}$. Con todo este arsenal jurídico, el Derecho Común fue calando en la práctica cotidiana y fueron, sobre todo, los escribanos quienes a través de una paciente labor de redacción de distintos documentos, inspirándose para ello en modelos procedentes de otras áreas peninsulares o incluso de la misma Italia, fueron introduciendo el Derecho Común ${ }^{77}$. Es muy factible pensar que el verdadero desencadenante de la penetración y aparición de las primeras manifestaciones del Nuevo Derecho fuesen, más que los textos y obras doctrinales, los trabajos desarrollados por los escribanos públicos con sus formularios inspirados en el derecho romano justinianeo. Diversos

${ }^{76}$ Vid. MARTÍNEZ SALAZAR, A., «Fragmento de un nuevo códice gallego de las Partidas», en Boletín de la Real Academia Gallega, 31 (diciembre, 1909) y 32 (enero, 1910). Imprenta y Fotograbado de Ferrer, La Coruña, 1910, pp. 1-18 (ahora también en Algunos temas gallegos. Segundo volumen. Gráficas do Castro, La Coruña, 1981, pp. 105-124; OVIEDO ARCE, E., en LÓPEZ FERREIRO, A. (dir.), Colección Diplomática de Galicia Histórica, ed. cit., doc. $\mathrm{n}^{\circ}$. 1, pp. 4-13 y doc. $\mathrm{n}^{\circ}$. 26, pp. 103-135; y GARCÍA Y GARCÍA, A., "Tradición manuscrita de las Siete Partidas», en Iglesia, Sociedad y Derecho, ed. cit., pp. 249-283.

${ }^{77}$ Papel que ha destacado GARCÍA Y GARCÍA, A., «En torno al derecho romano en la España medieval», en Estudios en homenaje a don Claudio Sánchez-Albornoz en sus 90 años. Anexos de Cuadernos de Historia de España, Buenos Aires, 1985. Tomo III, pp. 59-72. 
fueron los campos en los que se pudo observar esta primera penetración de las prácticas romanas.

\section{3.- ALGUNAS MANIFESTACIONES PUNTUALES DEL FENÓ- MENO DE LA RECEPCIÓN: EXAMEN DE DOCUMENTOS DE APLICACIÓN DEL DERECHO}

La mejor manera de descubrir el modo auténtico y específico mediante el cual operó la paulatina inserción del Derecho Común en el ámbito gallego se puede estudiar a través de la consulta y examen detallado de los documentos de aplicación del derecho, con el cotejo de los cuales se pondrá de relieve la asimilación de los derechos romano y canónico. Cierto es que deben diferenciarse dos categorías de documentos en su modo de operar respecto a la herencia romana.

Por un lado, se hallarán aquellos textos en los que se hace mención a algún tipo de cláusula, máxima o sentencia jurídica de antaño, que constituye una novedosa inserción acaso debida a la formación del notariado y a los inicios de ese progresivo proceso de asimilación de las soluciones jurídicas de aquel derecho. Probablemente, se puedan situar tales menciones entorno a los siglos XII y XIII, auténticas avanzadillas del proceso receptor, pero que en ningún instante presuponen el desconocimiento o el rechazo del derecho tradicional anterior, sino la mezcla o combinación de ambas corrientes jurídicas.

A partir del siglo XIII y, sobre todo, ya en los siglo XIV y XV, la educación y las bibliotecas demuestran una presencia constante del Derecho Común y consecuentemente las menciones y referencias al mismo no se circunscribirán a meras citas, sino que, en efecto, los diferentes actos y negocios jurídicos serán redactados y conformados con arreglo a los principios y categorías conceptuales del Nuevo Derecho. Se trata nuevamente de la distinción entre una primera "penetración» inicial, preliminar, que sienta las bases de una posterior «recepción» en el sentido de asimilar ya como forma jurídica el conjunto de nuevas soluciones que proporciona el nuevo derecho triunfante. Los documentos de aplicación del derecho serán los que nos muestren los ejemplos más palmarios de ese avance constante e imparable del Derecho Común con ánimo de reemplazar el viejo orden jurídico existente. Allí será decisiva la intervención de los 
escribanos o notarios (clérigos en su mayor parte) como auténticos artífices del cambio, como ya hemos indicado ${ }^{78}$.Veremos a continuación cuestiones referidas a la aparición de renuncias relativas a la leyes romanas, al derecho hereditario, al precio justo en la compraventa, la evolución de la institución del foro, concluyendo con una interesante sentencia de mediados del siglo XIII que puso de relieve la dualidad jurídica enfrentada. Debemos advertir que este trabajo tiene simplemente una finalidad indicativa, por lo que no hemos agotado la totalidad de recursos archivísticos y bibliográficos existentes sobre el particular. Hemos consultado aquellas colecciones diplomáticas y cartularios que nos parecen más representativos de las diversas regiones de Galicia y a partir de ahí seleccionamos los documentos que mejor se prestasen a la finalidad de estas líneas, sin, desde luego, ánimo alguno de concluir todas las reflexiones que esta materia tan compleja puede ir sugiriendo.

\section{1.- La renuncia a las leyes romanas}

El derecho altomedieval había supuesto un auténtico retroceso en cuanto a las modalidades existentes para la garantía y aseguramiento de los derechos adquiridos en las distintas relaciones jurídicas que los individuos concertaban. La ausencia en las primeras centurias medievales de un auténtico aparato político y de una poderosa maquinaria administrativa y jurisdiccional que permitiese el efectivo cumplimiento del derecho y la tutela del orden y de la paz social, provocó el florecimiento de toda una gama de instituciones que, de alguna forma, tendían a suplir el papel que

${ }^{78}$ Vid. BONO, J., Historia del Derecho Notarial español. Junta de Decanos de los Colegios Notariales de España, Madrid, 1979. Tomo I, pp. 165 ss., en donde se describe el paso del notario altomedieval, esencialmente escritor o redactor, al bajomedieval, que actúa ya como fedatario público. Para cumplir su misión es esencial el empleo de formularios y el desarrollo del ars dictandi, esto es, la corrección en la redacción de los textos y en la formulación de los negocios jurídicos (pp. 199 ss.). Acabará desembocando en el conocido ars notariae, cuyas figuras más representativas aparecen en la segunda mitad del siglo XIII: Rainero de Perugia, Salatiel y Rolandino Passegeri. Para el caso gallego, vid. BOUZA ÁLVAREZ, E., «Orígenes de la notaría. Notarios de Santiago de 1100 1400», en Compostellanum, vol. V, 4 (1960), pp. 233-412; y LUCAS ÁLVAREZ, M., «El notariado en Galicia hasta el año 1300 (Una aproximación)», en Actas del VII Congreso Internacional de Diplomática. Consellería de Cultura, Educació i Ciencia, Valencia, 1989. Tomo I, pp. 331-480. 
anteriormente correspondiera a los poderes públicos. La falta de potestad en los jueces y en los condes en su vertiente práctica determinó la aparición de mecanismos con arreglo a los cuales se trataría de fomentar la defensa de lo propio y regularizar un modo armónico con el que se cumpliesen las obligaciones varias contraídas. A estos motivos, obedecen, entre otras muchas instituciones, la figura de la prenda y la fianza extrajudicial ${ }^{79}$, modos todos ellos mediante los que se tratan de concordar las necesidades dimanantes de una precaria organización política y la estricta protección de los individuos y de sus situaciones jurídicas. Junto a ambas modalidades, desde la época visigoda, se fue desarrollando la prenda en su significación más próxima a lo que acontecía en la época romana, pero esta prenda contractual también fue evolucionando hacia soluciones jurídicas más complejas atendiendo a los intereses que se pretendían resolver. La prenda contractual medieval oculta en su seno una pluralidad de negocios jurídicos que se apartan de los precedentes góticos para caminar hacia la llamada prenda de usufructo. La intervención en esos negocios de monedas, a pesar del carácter escasamente monetario de la economía del período, fuerza a que aparezcan las primeras menciones a leyes romanas relacionadas con la institución.

A este respecto destacaba el profesor Iglesia Ferreirós que, prescindiendo de la aparición de formas de transición de la prenda que advierten el nacimiento de la hipoteca, de compleja evolución, el surgimiento de renuncias, típicamente referidas a cláusulas y a construcciones romanas, puede situarse a finales del siglo XII ${ }^{80}$. Concretamente, en relación a los contratos de prenda, la primera renuncia a la exceptio non numerata pecunia está datada en el año 1196 en la zona catalana ${ }^{81}$. Coetáneamente,

${ }^{79}$ Vid. ORLANDIS ROVIRA, J., «La prenda como procedimiento coactivo en nuestro derecho medieval (Notas para su estudio)», en Anuario de Historia del Derecho Español, XIV (1942-1943), pp. 81-183.

${ }^{80}$ Vid. IGLESIA FERREIRÓS, A., La garantías reales en el derecho histórico español. I. La prenda contractual: desde sus orígenes hasta la recepción del Derecho Común. Monografías de la Universidad de Santiago de Compostela, $\mathrm{n}^{\circ}$. 38, Santiago de Compostela, 1977, pp. 282 ss.

${ }^{81}$ Cfr. IGLESIA FERREIRÓS, A., Las garantías reales en el derecho histórico espa$\tilde{n} o l$, p. 341. Al referirse a las menciones que se hacen a los fideiussores, se concluye que «estas alusiones parecen mostrar la Recepción del derecho romano, que se va acentuando y que se pone de manifiesto sobre todo en estas cláusulas accesorias. Así como se

«CUADERNOS DE ESTUDIOS GALLEGOS», Tomo XLVIII, Fascículo 114, Santiago 2001. 
las mujeres contratantes prometen no ir contra la prenda establecida «per racionem sponsalicii siue per aliquam legem uel artem aut etiam per ullam aliam uocem ${ }^{82}$, renuncia que con el paso del tiempo adquirirá caracteres más explícitos y llegará a mencionar el rechazo a ampararse en el senadoconsulto Veleyano ${ }^{83}$, con lo que la romanización comenzaba a tomar visos de materializarse de forma plena. La aparición de la palabra «hipoteca» también tiene en Cataluña su primera región de expansión ${ }^{84}$.

La conversión detectada de la prenda en usufructo en una prenda sin transmisión del inmueble tiene su temprana aparición en documentos gallegos procedentes de Santiago de Compostela ${ }^{85}$. Y es en relación con estos numerosos contratos pignoraticios donde se observa la plácida y lenta inserción del derecho romano, expresado por medio de renuncias a las leyes de la non numerata pecunia y análogas. Hay que destacar, y de nuevo coincidimos con el profesor Iglesia Ferreirós, que las renuncias no

renuncia a la exceptio non numerata pecunia, en 1200 el fideiussor promete pagar la deuda omni remota exceptione, mientras en 1209 , los fiadores, quienes prometen unusquisque per totum al acreedor mantenerle en la pacífica posesión y disfrute de la prenda y le harán hoc pliuium pro pignore et expletis et auere, renuncia, salvo uno de ellos, el arzobispo, al privilegio de la epistola Adriani (...)».

${ }^{82}$ Cláusula que aparece por primera vez en un documento de 13 de abril de 1193, de acuerdo con IGLESIA FERREIRÓS, A., Las garantías reales en el derecho histórico español, pp. 347-348.

${ }^{83}$ Vid. LALINDE ABADÍA, J., «La recepción española del senadoconsultoVelleyano», en Anuario de Historia del Derecho Español, XLI (1971), pp. 335-371. Un ejemplo gallego, del siglo XV, en MARTÍNEZ SALAZAR, A., Documentos gallegos de los siglos XIII al XVI. Imprenta de la Casa de Misericordia, La Coruña, 1911, doc. $\mathrm{n}^{\circ}$. 63, pp. 146-47. Año 1434. Donación de Catalina Domínguez al monasterio de Caaveiro: «Sobre lo cual renunçio et parto de mi toda ley et todo dereyto asi canonico como ceuil et aley de Valiano que he en auda das molleres et aley que diz que geeral renunciaçon non valla et todas las outras boas razoes et defensoes que por mi podese dizer et alegar en contrario desto que dito he et en esta carta se conten».

${ }^{84}$ Cfr. IGLESIA FERREIRÓS, A., Las garantías reales en el derecho histórico espa$\tilde{n} o l$, p. 134. El término aparece testimoniado en tiempos de Pedro II (año 1204), para hallarse más adelante en documentación de los años 1208 y 1211. Es aceptado sin paliativos en las Costums de Lérida y en la legislación de Jaime I. A mayores, vid. pp. 373 374. en el caso gallego, la primera referencia data del año 1265 , conforme al testimonio de MARTÍNEZ SALAZAR, A., Documentos gallegos de los siglos XIII al XIV, ed. cit., doc. $\mathrm{n}^{\circ} .42$, pp. 89-90, aunque no se menciona la voz «hipoteca».

${ }^{85}$ Cfr. IGLESIA FERREIRÓS, A., Las garantías reales en el derecho histórico español, p. 297. 
deben ser contempladas como las manifestaciones palmarias del triunfo sin paliativos del Derecho Común y de su consecuente aplicación, sino más bien el.resultado del choque entre dos sistemas jurídicos de los cuales solamente uno podría subsistir. Como bien expresa el autor al que seguimos, «las renuncias $-\mathrm{y}$ en este sentido la renuncia a la hipoteca a favor de la dote de la mujer sobre los bienes del marido-no serían así el reconocimiento de la aplicación del derecho de la Recepción, sino el intento de protegerse ante la aceptación del mismo», siendo la posición social de las partes, la educación de los jueces y asesores la que determine el triunfo de una u otra solución jurídica ${ }^{86}$.

Algunos cartularios gallegos dan cumplida cuenta de la inserción, por la voluntad y sapiencia del escribano de turno, de algunas renuncias en las que se está haciendo referencia expresa a la legislación romana, cosa sorprendente en la centuria a la que pertenecen. El caso más usual es la presencia la exceptio non numerata pecunia, de raigambre romana, inspirada en una constitución de Antonino Pío, del año 215. En virtud de la misma, el demandado la podía oponer en el caso de estipulación documentada y cuando no se hubiera hecho entrega de la cantidad reclamada, invirtiendo la carga de la prueba: era el acreedor quien debía probar la relación en que se fundaba el pago, la causa de la estipulación ${ }^{87}$. Ni qué decir tiene que las fuentes visigodas y altomedievales guardan silencio al respecto. Pero la situación sufre una mutación en el siglo XII.

\footnotetext{
${ }^{86}$ Cfr. IGLESIA FERREIRÓS, A., Las garantías reales en el derecho histórico español, p. 299: «La enemiga campesina contra la Recepción resulta así clara: no va dirigida contra un derecho que no entienden, para defender su derecho tradicional, su derecho de toda la vida, sino que es el desesperado intento de defender los propios intereses. Frente a la invocación de la mayor justicia del derecho de la Recepción se trata de mantener, en último término, el principio de que las situaciones jurídicas establecidas de acuerdo con un determinado sistema jurídico deben ser resueltas de acuerdo con el mismo y no por medio de los principios de otro sistema jurídico, que responden a otros presupuestos, aunque se pretenda presentarlo como mucho más justo, como expresión de la razón natural».

${ }^{87}$ Vid. GARCÍA GARRIDO, M. J., voz «Exceptio non numeratae pecuniae», en Diccionario de Jusriprudencia romana. Editorial Dykinson, Madrid, 1982, p. 128. Más tarde se concede además una querella, con la que el deudor podía accionar contra el acreedor para obtener la anulación de la estipulación. Justiniano fijó un plazo de dos años para ejercitar la acción o interponer la excepción, transcurrido el cual se atribuye carácter constitutivo al documento escrito.
} 
El testimonio más antiguo data del año 1165: es el caso de una venta realizada entre el arzobispo de Santiago y un matrimonio, actuando como mediador un porcionero de la catedral. Los vendedores renuncian «exceptioni dictorum denariorum nobis non numeratorum et non traditorum $\rangle^{88}$. A partir de ese instante, deviene una cláusula usual en compraventas, trueques o permutas, y en donaciones, como se infiere de diferentes cartularios y colecciones diplomáticas ${ }^{89}$. En los documentos pertenecientes al monasterio de Oseira, podemos leer en una compraventa de 1273:

«Totum enim precium quod nobis et eis placuit, videlicet, trescentos morabitinos monete alfonsi alborum predicto casali ad eis non confitemur integre recepisse in pecunia numerata, renunciantes omni exceptioni non tradite et non numerate pecunie supradicte» ${ }^{90}$.

En la colección diplomática del monasterio de Ferreira de Pantón, podemos ver la existencia en el siglo XV de esta cláusula perfectamente asimilada: en una venta celebrada entre el notario de Lugo, Gómez Fernández, y Xoán Rodríguez, en el año 1409, se dice «et renunçio a exçepçon do aver non contado nen visto nen avido nen reçebido, et a outra exçepçon de enganno et dereito que en contrario do que sobredito he por min ouvese et podese aver dizer nen alegar en juycio nen fora del

${ }^{88}$ EXTREMADOURO FIGUEROA, M. M., La colección diplomática del Tumbo $C$. Parte Primera. Tesina de Licenciatura. Facultad de Filosofía y Letras, Santiago de Compostela, 1967, doc. $\mathrm{n}^{\circ}$. 35. Año 1165.

${ }^{89}$ A modo de ejemplo, vid. ENRÍQUEZ PARADELA, M. C., Colección diplomática del monasterio y convento de Santo Domingo de Ribadavia. Boletín Auriense. Anexo, 8. Museo Arqueológio Provincial, Orense, 1987, doc. $n^{\circ}$. 4, pp. 72-73. Año 1393.

${ }^{90}$ ROMANÍ MARTÍNEZ, M., Colección diplomática do mosteiro cisterciense de Sta. María de Oseira (1025-1310). Tórculo Artes Gráficas, S. L., Santiago de Compostela, 1989. Tomo I, doc. $n^{\circ}$. 151, pp. 155-156. Año 1213. Junto a otras renuncias, como en Tomo II, doc. 1.224, p. 1.162. Año 1292: «Et renuncio que nuncha contra esta vençon al possa diser nen façer»; doc. $\mathrm{n}^{\circ}$. 1.327 , p. 1.257. Año 1305: «Et renunço que non possa dizer que os ditos dineiros a min nen forom pagados et contados et en meu jur reçebudos»; Tomo III, doc. $n^{\circ} .1 .384$, p. 19. Año 1314: «Et todas las outras cousas, segundo sobredito he, quitamos et renunçiamos que nonca as possamos demandar nos nen nossa voz, et se o demandasemos que non valla en juizo nen fora del».

«CUADERNOS DE ESTUDIOS GALLEGOS», Tomo XLVIII, Fascículo 114, Santiago 2001. 
en nihua nen algua maneira $»^{91}$. En otro documento similar, de fecha 1412 , se expresa «et obrigo min e todos meus bees avidos e por aver de voz fazer de pao a dita vençon a todo tempo, pera o qual todo e çerca delo renunçio a exçepçon de numerata pecunya e todo o outro dereito que en meu ajuda seeria pera yr conta esta dita vençon» ${ }^{92}$. Otra venta de 1417 dice: «et renunçio sobre elo á ley e exsepçón da innumerata pecunia»»"

Sucede de modo idéntico en el caso del monasterio de Santo Domingo de Ribadavia, en dos documentos que traemos a colación ya en una época posterior: una venta celebrada en el año 1436 demuestra la perfecta imbricación del sistema romano al decirse que «que uso arrecevi de que uso outorgo por ven entrego e pago renuncio meu direito e a ley e a prematica de numerata pecunia» ${ }^{94}$. En una donación posterior, se expresa lo siguiente:

«E sobre esto renunçio e parto de min e miñas voses a todoas las leis e foros e dereitos canonicos e cevis escritos o non escritos e todas las outras boas raçoes eixeiçoes e a ley que diz que general renunçiaçion non valla e a ley de emperadores que fala en çinpleza das molleres» ${ }^{95}$.

En otro documento de 1447 se indica: «Et obrigo mi et todos meus bees avidos et por auer de uoz fazer de paz adita vençon todo tempo et quito et renunçio alei do auer non contado ne rreçibido ne visto do notario et aquela ley que diz que en tempo de dous años deue conprador demostrar en como feço apaga ao vendedor en dineyros ou en outra cousa que os valla et rençio aquela ley eycepçon que diz que geral renunciaçon non valla et todas las outras leyes et foros et dereytos que en contrario da dita

${ }^{91}$ FERNÁNDEZ DE VIANA Y VIEITES, J. I., Colección diplomática del monasterio de Santa María de Ferreira de Pantón. Servicio de Publicaciones de la Excma. Diputación Provincial de Lugo, Lugo, 1994, doc. $n^{\circ}$. 110, pp. 131-132.

${ }^{92}$ FERNÁNDEZ DE VIANA Y VIEITES, J. I., Colección diplomática del monasterio de Santa María de Ferreira de Pantón, ed. cit, doc. ${ }^{\circ} .119$, p. 142.

${ }^{93}$ FERNÁNDEZ DE VIANA Y VIEITES, J. I., Colección diplomática del monasterio de Santa María de Ferreira de Pantón, ed. cit., doc. $\mathrm{n}^{\circ} .130$, p. 158.

${ }^{94}$ ENRÍQUEZ PARADELA, M. C., Colección diplomática del monasterio y convento de Santo Domingo de Ribadavia., ed. cit., doc. $\mathrm{n}^{\circ}$. 15, pp. 80-81. Año 1436.

${ }^{95}$ ENRÍQUEZ PARADELA, M. C., Colección diplomática del monasterio y convento de Santo Domingo de Ribadavia, ed. cit., doc., $\mathrm{n}^{\circ}$. 16, pp. 82-83. Año 1454. 
venço poderian dizer et alegar en algun tempo» ${ }^{96}$. Otra venta posterior expresa idéntica idea ${ }^{97}$.

La práctica de estas renuncias por medio de la cuales la parte firmante rechaza algunos derechos subjetivos que lo asisten a consecuencia de la relación jurídica contenida en el documento será cada vez más frecuente en el sistema de Derecho Común consolidado en las siguientes centurias ${ }^{98}$.

\section{2.- Documentos referidos al derecho hereditario}

Es en el campo de los documentos referidos al derecho hereditario donde se puede observar una clara y más intensa recuperación de los esquemas romanos. Si el testamento en su concepción latina había sido abandonado en el período altomedieval, apareciendo en su lugar una serie de figuras que desempeñaban funciones análogas (donaciones por causa de muerte, donaciones con reserva de usufructo, donaciones a favor del alma, las mandas entre parientes, etc.), lo cierto es que a lo largo del siglo XIII se hallan numerosos ejemplos de testamentos elaborados more romano, o, lo que es lo mismo, con la presencia de una cláusula en la que se recoge una creación de esas raíces como es la institución del heredero. Los documentos son abundantes en tal sentido y casi se puede afirmar la existencia de un estilo notarial, procedente con toda probabilidad de algún Ars Notariae llegado a Galicia junto con otros volúmenes de Corpus Iuris, o de algún escribano formado con arreglo a los estilos romanos que plasma después en sus escrituras todos los conocimientos adquiridos.

Frente a los testamentos altomedievales en los cuales no se hace referencia alguna a la figura del heredero y el modo en que opera la sucesión

${ }^{96}$ MARTÍNEZ SALAZAR, A., Documentos gallegos de los siglos XIII al XVI, ed. cit., doc. $n^{\circ}$. 67, pp. 148-150. Año 1447. Venta de Mayor Alfonso a Juan Fernández de Saa.

${ }^{97}$ MARTÍNEZ SALAZAR, A., Documentos gallegos de los siglos XIII al XVI, ed. cit., doc. $\mathrm{n}^{\circ}$. 72, pp. 165-168. Año 1516. Venta de Juan espiga a fray Lopo Espiga: «O dito Juan Espiga me dou et otorgo por contento et pago a todo meu plazer et vontade et en razon de la paga renunçio la excibçion et ley que fala enrazon do engaño do aber nombrado no visto ni dado ni contado ni resçebido et una ley que dize quelos testigos dela carta deben fazer la paga en dineiros (...)».

${ }^{98}$ Vid. PÉREZ-PRENDES, J. M., «General renunciacion non vala. Sobre doctrina y práctica en tiempo del Ius Commune», en Glossae. Revista de Historia del Derecho Europeo, 5-6 (1993-1994), pp. 75-114. 
hereditaria se aproxima más bien a una donación que a un auténtico testamento, los documentos que ahora pasamos a mencionar dan muestras cumplidas de la existencia de una nueva manera de configurar este negocio hereditario por medio de la referencia expresa a la institución del heredero, desconocida con anterioridad a esa fecha ${ }^{99}$. Junto a esas referencias, no deja de sorprender la aparición al mismo tiempo de otras instituciones típicamente romanas y desconocidas en el período medieval que se estaba cerrando. Obvia decirlo: son todas instituciones notoriamente alejadas de los parámetros entre los que se movía el derecho hereditario altomedieval y responden, por ende, a toda una nueva gama de influencias atribuibles a las circunstancias ya reseñadas y conocidas.

El testamento altomedieval es, antes que nada, una disposición por razón de muerte a través de la cual el testador procede a la distribución de sus bienes sin seguir unos criterios legales perfectamente definidos. Hay una absoluta libertad para disponer de los bienes y una absoluta libertad en cuanto a la forma jurídica que se va a emplear para hacerlo, sin sujeción a los estrictos formalismos del derecho romano ${ }^{100}$. Ni en la legislación visigoda, ni en el Fuero Real, primer intento de romanización jurídica reseñable en el

${ }^{99}$ Elemento indispensable, sin embargo, en el testamento romano, de acuerdo con D’ORS, A., Derecho Privado Romano. $7^{\text {a }}$ edición revisada. EUNSA, Pamplona, 1989, pp. 297 ss.

${ }^{100}$ Vid. GARCÍA-GALLO, A., «El problema de la sucesión mortis causa en la Alta Edad Media española», en Anales de la Academia Matritense del Notariado, tomo X (1959), pp. 2248-276; y «Del testamento romano al medieval. Las líneas de su evolución en España», en Anuario de Historia del Derecho Español, XLVII (1977), pp. 425-497 (Ambos recogidos en sus Estudios de Historia del Derecho Privado. Publicaciones de la Universidad de Sevilla, Sevilla, 1982, por donde citamos). Más en profundidad, ARVIZU Y GALARRAGA, F., La disposición mortis causa en el Derecho español de la Alta Edad Media. EUNSA, Pamplona, 1977, pp. 129 ss., quien habla de la decadencia del testamento romano y visigodo (salvo zonas específicas), que pasa a ser una declaración solemne y firme, de contenido muy diverso que deviene un instrumento genérico del derecho, en vez de ser una figura típica perfectamente delimitada: «La evolución del Derecho altomedieval tiende hacia una nueva fórmula hereditaria, donde, por las circunstancias especiales en las que la vida se desenvuelve, la comunidad familiar en torno a la tierra adquiere una excepcional importancia. En este contexto, la sucesión voluntaria era algo carente de sentido, y el recurso al testamento, innecesario. La sucesión legítima -la única sucesión- es la que se produce a la muerte del causante. Las disposiciones que con diversa eficacia haya podido establecer el muerto son actos por los que los herederos no tienen más remedio que estar y pasar. Ahora bien, en el caso de morir una persona sin hijos, el planteamiento es distinto, y las soluciones varían según lo prueban los distintos

«CUADERNOS DE ESTUDIOS GALLEGOS», Tomo XLVIII, Fascículo 114, Santiago 2001. 
derecho castellano, se contempla la necesidad de instituir heredero para que los testamentos fuese plenamente válidos. Como expresa García-Gallo, el heredero en el mundo romano era el que recibía la herencia a la muerte del causante y el serlo presuponía el fallecimiento de éste. Sin embargo, en la Alta Edad Media, herederos «son, aun en vida del titular, los que a su muerte pueden adquirir sus bienes, aunque acaso no lleguen a recibirlos si el propietario dispone de ellos» ${ }^{101}$. La penetración del derecho romano permite atisbar cambios en este sentido. Algunos ejemplos ponen esto de manifiesto, ejemplos que son bastante tempranos en comparación con otras zonas de la Península Ibérica. Es el caso del testamento de Egidio, prior de San Martín de Santiago, en el que instituye heredero a Pedro Petriz, datado el 31 de enero de 1164, en el que se expresa lo siguiente:

"Instituo mihi heredes mei in omnibus bonis meis (...) et ipse compleat missiones meas tanquam heres meus legitimus sine dapno».

para referirse más adelante al mismo como «ipsi heredi et fratri meo» ${ }^{102}$. Algunos documentos son híbridos entre el sistema altomedieval y el del Derecho Común, entre la carta de donación y el testamento romano ${ }^{103}$. En otro documento del año 1190, se alude a la institución del heredero y al codicilo ${ }^{104}$.

ordenamientos. El hecho de que disponga de todos sus bienes en el caso en que pueda hacerlo, no quita para que no se acuda a la figura del testamento, por otra parte desconocida en casi toda la Península», en ob. cit., p. 132. El testamento es reemplazado por otras figuras como las donaciones pro anima entregadas en vida del donante, las donaciones post obitum, las donaciones con reserva de usufructo, ordinationes, mandas, etc.

${ }^{101}$ Cfr. GARCÍA-GALLO, A., «El problema de la sucesión mortis causa en la Alta Edad Media española», en Estudios de Historia del Derecho Privado, p. 259.

${ }^{102}$ El texto en FERNÁNDEZ VILLAMIL, E., «Documentos medievales del Museo de Pontevedra. Siglos XII-XIII», en El Museo de Pontevedra, 2 (1943), pp. 112-113.

${ }^{103}$ EXTREMADOURO FIGUEROA, M. M., La colección diplomática del Tumbo $C$, doc. $\mathrm{n}^{\circ}$. 46. Año 1173: «Ego Marie Arie proprie uoluntatis arbitrio et amicorum meorum exortate consilio propinquiores de genere meo locorum filiorum heredes constituere, cum filios non haberem».

${ }^{104}$ MOURIÑO SERANTES, M., El Tumbo $C$ de la Catedral de Santiago, doc. $\mathrm{n}^{\circ}$. 55. Año 1190: «Porro si series testamenti diligenter inspicitur ecclesia relinquitur heres cum heredes meis sub conditione et pro tempore forte constituuntur (...) et hoc legitimum factum sempiternum robur obtineat presenti in pagina codicellum meum quem de aliis hereditatibus condidi».

«CUADERNOS DE ESTUDIOS GALLEGOS», Tomo XLVIII, Fascículo 114, Santiago 2001. 
En el siglo XIII, las imprecisiones de antaño han dado paso a la aceptación plena de las fórmulas romanas ${ }^{105}$. En el testamento del arcediano compostelano don Abel Fernández, del año 1232, se dice expresamente:

«Insuper super omnia bona tam habita quam habenda mobilia et inmobilia constituo heredem meum ipsum alffonsum petri iam superius nominatum consanguineum meum, filium Petri pelagii patruy mei qui bene et fideliter compleat omnia que mando» ${ }^{106}$.

Idea que se reitera en documentos de fechas próximas, todos pertenecientes al siglo XIII, recogidos en el mismo catálogo documental ${ }^{107}$, en

${ }^{105}$ Vid. FERNÁNDEZ DE VIANA Y VIEITES, J. I., La colección diplomática del monasterio de Santa María de Penamayor. Tesis Doctoral. Facultad de Filosofía y Letras, Santiago de Compostela, 1971, p. 33, con las referencias documentales al respecto.

${ }^{106}$ LÓPEZ FERREIRO, A. (dir.), Colección diplomática de Galicia Histórica, ed. cit., doc. $\mathrm{n}^{\circ}$. XXXVI, p. 180.

${ }^{107}$ LÓPEZ FERREIRO, A. (dir.), Colección diplomática de Galicia Histórica, ed. cit., doc. $n^{\circ}$. XXXIX, p. 187. Testamento de don Abel Fernández. Año 1269: «Instituo mihi heredes domnum Pelagium iohannis iudicem compost. et johannem elie campsorem consanguineos meos in omnibus residuis bonis meis mobilibus et inmobilibus»; doc. $\mathrm{n}^{\circ}$. XL, p. 192. Testamento de don Pelayo Eans, juez de Luou y canónigo. Año 1270: «Instituo heredes meos in omnibus bonis meis residuis donmum Petrum uilielmi Cantorem auunculum meum Petrum fidelis consanguineum meum et Maiorem iohannis sororem meám in singulis quartis»; doc. $\mathrm{n}^{\circ}$. XLVI, p. 224. Testamento del cardenal de Santiago, don Lorenzo Domínguez. Año 1276: «Instituo mihi heredes meos in omnibus bonis meis mobilibus et inmobilibus fratres meos Archidiacono de Regina in compostellana ecclesia et dictam Mariam dominici sororem meam et suam utrumque scilicet in medietate»; doc. $\mathrm{n}^{\circ}$. LII, p. 238. Testamento del canónigo Juan Pérez. Año 1245: «Instituo ipsum Benedictum heredem in quarta parte bonorum Johannis payronethe que nondum sunt a me percepta. Concedo ei omnes acciones quas habeo tam contra heredes, quam contra debitores hereditarios. Quam etiam contra donnam marinam pelagii uxorem quondam Johannis peyronethe super bonis ipsius Johannis peyronethe et uolo quod sciat ipse Benedictus (...) Et instituo et facio ipsum heredem meum in omnibus meis tam mobilibus quam inmobilibus sine dampno suo excepta institutionem Benedicti ffernandi si ipse B. ipsam uoluerit acceptare»; doc. $\mathrm{n}^{\circ}$. LIII, p. 242. Testamento del tesorero don Pedro Abril. Año 1279: «Instituo heredem meum et completorem meum istius mei testamenti fratrem meum donnum Martinum aprilis in residuis bonis meis mobilibus et in tenentia donni Pelagii camundi quodan Compost Archiepo"; doc. $\mathrm{n}^{\circ}$. LIV, p. 245. Testamento de don Nuño Fernández, arcediano de Salnés. Año 1276: «It. instituo michi heredes donnum Petrum fidelis magistrum scolarum fernandum roderici et iohannem petri canonicos nepotes meos in singulirs tertiis, et cum aliquis eorum predecesserit ad superstites pars

«CUADERNOS DE ESTUDIOS GALLEGOS», Tomo XLVIII, Fascículo 114, Santiago 2001. 
algunos casos con construcciones más complejas, como en el caso del testamento de doña Teresa Yáñez de Deza, donde se dice:

«Et mando et concedo et confirmo domno Alfonso marito meo in tota su uita donationes et mandam (...) Et mando et uolo et facio meos filios heredes meos de omnia» ${ }^{108}$.

En esa centuria aparece el primer documento hereditario redactado plenamente en romance: el testamento de Vasco López de Ulloa, del año 1262 , con idénticas referencias implícitas al derecho romano en cuanto a la designación del heredero ${ }^{109} \mathrm{y}$ a la revocación de toda anterior declaración de voluntad ${ }^{110}$.

En fechas posteriores, se comienza a usar de forma usual el romance para la redacción de los correspondientes documentos. Así se puede leer en el testamento del arcediano de Reina don Nuño González de Bendaña, del año 1348:

illius immobilium deuolatur et si procedat usque ad ultimum quo defuncto bona omnia immobilia qua ad ipsos heredes ratione huius institutionis peruenerunt»; doc. $n^{\circ} . L V, p$. 253. Testamento del canónigo de Santiago don Alonso Pérez. Año 1283: «Instituo mihi heredes in residuis bonis meis mobilibus et inmobilibus donnum ariam petri archidiaconum de salnes in quarta excepto quod uolo et mando quod in pannis et perfiis domus mee non diuidat cum aliis heredibus meis»; doc. $\mathrm{n}^{\circ}$. LVIII, pp. 263-264. Testamento de don Alfonso Ruíz de Bendaña. Año 1253: «Instituo predictum monasterium de Camancio heredem meum in omnibus residuis bonis meis tam mobilibus quam immobilibus ubicumque sint et in ipsum transfero dominium et possessionem ipsorum bonorum per traditionem istius mei testamenti quod in presenti trado donno johanni fernandiz abbati et donno Sebastiano pelagii priori eiusdem monasterii qui presentes sunt et concedunt et ipsi abbas et prior et conuentus soluant omnia debita mea que ego debeo et compleant hoc testamentum et omnes missiones meas et recipiant et habeant omnia debita que mihi debentur et mulum meum quem eis uendo pro CCC sol ad debita mea soluenda. Si quis igitur, etc.».

${ }^{108}$ LÓPEZ FERREIRO, A. (dir. ), Colección diplomática de Galicia Histórica, ed. cit., doc. $\mathrm{n}^{\circ}$. LIX, p. 266. Año 1262.

${ }^{109}$ LÓPEZ FERREIRO, A. (dir.), Colección diplomática de Galicia Histórica, ed. cit., doc. $n^{\circ}$. LXXV, p. 322: «E fazo meus herderos a Vasco lopez de parrega et a Don Jerbas crego de san juyao do camino (...)».

$1^{110}$ LÓPEZ FERREIRO, A. (dir.), Colección diplomática de Galicia Histórica, ed. cit., doc. $n^{\circ}$. LXXV, pp. 322-323: «Otrosi mando seya semper valida e esta manda esta en seu robur seo on quiser toler ou cader en esta manda (...) Et con todas as outras mandas e todos os outros testamentos que eu fige atrás aquí non vallan. E esta seya para semper y dedeyra».

«CUADERNOS DE ESTUDIOS GALLEGOS», Tomo XLVIII, Fascículo 114, Santiago 2001. 
«Faço et establesco meus herees ennos outros meus bees os dictos arcidiago don alfonso Sanchez et Gonzalo Sanchez et Garcia martis meus sobrinos cada hun en senllos terços. Et faço compridores desta mia manda don frey Nicolao prior do moesteyro de bonaual et o dicto Arcidiago meu sobrino et Bertolameu peres criado de dom Lorenzo peres Chantre que fuy de Santiago (...) $)^{111}$.

Pero no sólo es en sede de institución hereditaria donde se detectan algunas innovaciones desconocidas en el período altomedieval procedentes de la recuperación del derecho romano. En algunos textos se puede observar la existencia de nuevas inserciones de figuras típicamente romanas, ausentes en los cartularios y en la documentación de centurias anteriores, como pueden ser los casos de las sustituciones hereditarias ${ }^{112}$, la presencia de codicilos $^{113} \mathrm{o}$ la inserción de la llamada cláusula de salvaguarda por medio de la cual se hacía valer como simple codicilo el testamento que no reuniese todos los requisitos exigidos para su plena eficacia ${ }^{114}$. En algunos casos, falta en el testamento la correspondiente institución del heredero, apareciendo en su lugar legados y no mandas como en la época altomedieval ${ }^{115}$.

${ }^{111}$ LÓPEZ FERREIRO, A. (dir.), Colección diplomática de Galicia Histórica, ed. cit., doc. n $^{\circ}$. LXXII, p. 309. Año 1348.

${ }^{112}$ LÓPEZ FERREIRO, A. (dir.), Colección diplomática de Galicia Histórica, ed. cit., doc. $n^{\circ}$. XLVI, p. 224: «In morte uero predicti Archidiaconi fratris mei volo instituo et mando quod medietas sua de omnibus bonis inmobilibus tam in ciuitate compostellana quam extra in quibus heredem meum Instituo remaneat marie dominici et heredibus suis»; doc. $n^{\circ}$. LII, p. 238: «Volo preterea quod si predictus frater meus noluerit uel non potuerit esse heres. Instituo Ecclesiam compostellanam heredem predicto fratri meo».

${ }^{113}$ LÓPEZ FERREIRO, A. (dir.), Colección diplomática de Galicia Histórica, ed. cit., doc. $\mathrm{n}^{\circ}$. LIV, pp. 246 ss. Codicilo de don Nuño Fernández: «Nouerint universi quod impresencia testium subscriptorum ad hoc uocatorum et rogatorum donnus N. fernandi archidiaconus de Salnes dedit mihi Dominico petri Notario compostellano istam cedulam seu Codicillum quod eam Reddigerem in publicam formam quam uoluit et dixit cum testamento suo ut codicillum (...)».

${ }^{114}$ LÓPEZ FERREIRO, A. (dir.), Colección diplomática de Galicia Histórica, ed. cit., doc. $\mathrm{n}^{\circ}$. LIII, p. 242: «et si hec ordinatio mea uoluerit ut testamentum, ualeat ut codicillus uel quelibet alia ultima uoluntas»; doc. $\mathrm{n}^{\circ}$. LV, p. 254: «Et si hoc testamentum, non ualuerit ut testamentum, ualeat ut Codicillus uel ultima mea uoluntas uel eo modo quod magis ualere potest».

${ }^{115}$ LÓPEZ FERREIRO, A., (dir.), Colección diplomática de Galicia Histórica, ed. cit., doc. $\mathrm{n}^{\circ}$. XXXVII, pp. 181-182. Testamento del arcediano Payo Sebastiánez. Año 1232: «Lego praeterea quod det annuatim $\mathrm{C}$ pauperibus unicuique III denarios in 


\section{3.- El justo precio en la compraventa}

Siguiendo la autorizadísima opinión del profesor Iglesia Ferreirós, otro de los aspectos en los que se puede observar la iniciación del tránsito hacia el nuevo sistema del Derecho Común es en sede de compraventa, a propósito concretamente de la cuestión referida al «justo precio» y su correlativa consecuencia referida a la rescisión por lesión enorme ${ }^{116}$.

En el derecho romano justinianeo, se admitió para la venta de inmuebles la posibilidad de rescisión del contrato por la existencia de precio injusto, esto es, cuando fuese inferior a la mitad del valor verdadero del bien ${ }^{117}$. La influencia del cristianismo fue evidente para que Justiniano redactase las correspondientes constituciones que admitieran esta posibilidad en donde aparecían a modo de justificación consideraciones de tipo moral o ético, en consonancia con lo que era el ambiente jurídico del momento con una fuerte presencia de la religión y sus valores.

A pesar de tales indicaciones, el derecho visigodo siguió las directrices marcadas por el derecho anterior y, por lo tanto, no admitió el nuevo sistema impuesto por Justiniano. No obstante, varias leyes del Liber Iudiciorum se refieren al precio justo, aunque su significación no encaje en los moldes justinianeos. Así se puede ver en Liber 5, 4, 6, donde se dice: «Si in contractu venditionis minus pretium datum fuerit, et per fraudem, aut etiam contra voluntate venditoris amplius datum pretium

supradicto festo (...) Lego domum que fuit de Calcabardas filii Pelagii (...)». De acuerdo con ARVIZU Y GALARRAGA, F., quien sigue a Paulo Merêa, La disposición mortis causa en el Derecho español de la Alta Edad Media, ed. cit, pp. 222-223, la palabra «manda» expresaba originariamente las recomendaciones hechas en testamentos o disposiciones análogas, para pasar a designar con posterioridad una donación singular atribuida en otro documento de contenido más amplio, equiparándose con testamento.

${ }^{116}$ Cfr. IGLESIA FERREIRÓS, A., «Breviario, recepción, Fuero Real: tres notas», pp. 145-146.

${ }^{117}$ Cfr. D’ORS, A., Derecho Privado Romano, ed. cit., p. 544: «Esta rescisión por lesión enorme fue interpretada entre los comentaristas y legisladores medievales como una exigencia de la moral contractual y, en consecuencia, fue extendida a la venta de muebles y aun a favor del comprador, cuando se consideraba éste lesionado por haber pagado por encima de una mitad más del verdadero valor de la cosa comprada». Los textos sobre esta modificación pueden consultarse en C. Just. 4, 44, 2 y 8 . A mayores, vis. GUTIÉRREZ ALVIZ, F., «Laesio enormis (Revisión de conjunto con una nota sobre la legislación histórica española)», en Boletín de la Universidad de Granada, vol. XVII, 80 (1945), pp. 379-408.

«CUADERNOS DE ESTUDIOS GALLEGOS», Tomo XLVIII, Fascículo 114, Santiago 2001. 
nuncietur, quatum de iusto pretio fraudatum est, tantum duplum emptor restituat venditori» ${ }^{118}$. De la misma manera, Liber 5, 4, 7, expone que: "Venditiones haec forma servetur, ut seu res aliquae, sive terrae, vel mancipia, vel quodlibet animalium genus venditur, nemo propterea firmitatem venditionis inrumpat, eo quod dicat rem suma vili pretio venidisse», para indicar la firmeza del contrato.

Como expresa claramente el profesor D'Ors, la idea de precio justo que opera en la legislación visigoda no presenta conexión alguna con la teoría de la lesión enorme, sino que «precio justo» se refiere al convenido y debido por el mismo contrato, esto es, al precio pactado ${ }^{119}$. Toda venta firme deviene, pues, inatacable, no rescindible, desde el momento en que se cumplen los requisitos mínimos exigidos por la legislación. Los documentos altomedievales harán cumplida referencia al precio pactado por las partes, dirán que se tienen por bien pagados, sin ninguna deuda subsistente, $\mathrm{y}$, en consecuencia, la venta desprenderá todos sus efectos ${ }^{120}$.

\footnotetext{
${ }^{118}$ Cito por la edición de Los Códigos españoles concordados y anotados. $2^{\mathrm{a}}$ edición. Antonio de San Martín, Editor, Madrid, 1872. Tomo I.

${ }^{119}$ Cfr. D’ORS, A., Estudios Visigóticos II. El Código de Eurico. Edición, palingenesia e índices por Álvaro D’Ors. Cuadernos del Instituto Jurídico Español, Roma-Madrid, 1960, p. 217.

${ }^{120}$ SÁEZ, E. y SÁEZ, C., Colección diplomática del monasterio de Celanova (8421230). Servicio de Publicaciones de la Universidad de Alcalá de Henares, Alcalá, 19962000. Tomo I. doc. $\mathrm{n}^{\circ}$. 8, pp. 68-69. Año 905: «Et in tuo iuri vel dominio sint traditas atque confirmatas»; doc. $\mathrm{n}^{\mathrm{o}}$. 16, pp. 78-79. Año 922: «Et accepimus de uos precium, que nobis bene complacuit (...) et de ipso precio nichil remansit in debitum»; Tomo II, doc. $\mathrm{n}^{\circ} .173$, pp. 155-156. Año 970: «Pro que accepimus de uos precio in VIIII modios in cibaria et res que mihi bene complacuit, et de ipso precio apud uos nichil remansit indebito». Pronunciamientos similares en Tomo II, doc. $\mathrm{n}^{\circ}$. 179, p. 165. Año 974; doc. $\mathrm{n}^{\circ} .193$, p. 203. Año 983; y doc. $\mathrm{n}^{\circ}$. 201, p. 221. Año 987; y LUCAS ÁLVAREZ, M., La colección diplomática del monasterio de San Lorenzo de Carboeiro. Imprenta Góngoa, Madrid, 1958, doc. $\mathrm{n}^{\circ} .35$, p. 86. Siglo XII: «Et accepimus de te pretio LII solidos de mertoleses, que nobis bene complacuit ea de ipso pretio aput te nichil remansit in debitum, ita ut de hodie die et tempore de iuri nostro abrasa et in uestro iure sit tradita atque confirmata»; doc. $n^{\circ}$. 37, pp. 88-89. Año 1110: «Porque accepimus de uso precio, hic est, solidos VIII, de genarios de rexelos VI, de çevaria modios II, tantum nobis bene complacui, et apu uso michil remansit in deuito, ut de eas tu et omnis posteritas uestras»; y doc. $\mathrm{n}^{\mathrm{o}}$. 50, p. 105. Año 1145: « $\mathrm{I}^{\circ}$ marco de argento tantum mihi bene complacuit, et de precio apud uso nichil remansit iure uel dominio sit tradita, habeatis et possideatis et faciatis de illa quocumque uolueritis».
}

«CUADERNOS DE ESTUDIOS GALLEGOS», Tomo XLVIII, Fascículo 114, Santiago 2001. 
Por tanto, frente a la conservación de los esquemas jurídicos romanovulgares, tal y como han demostrado los estudios de Ramón Fernández Espinar $^{121}$ y de Jean Bastier ${ }^{122}$, es sorprendente la aparición y consolidación de fórmulas jurídicas en la zona galaico-asturiana en la que se hace referencia de manera clara y contundente a esa doctrina de la lesión y consecuente rescisión por precio injusto.

Se puede ver en los siguientes documentos extraídos del área asturiana. El primero de los que vamos a mencionar se refiere a una venta concertada entre Domingo Citiz, mujer e hijos, que venden a García Suárez y esposa una tierra en el valle de Teberga, en el cual se dice expresamente al tratar la cuestión del precio: «Vendimus ea ex integra, et accepimus de vos in pretio qrs duos in pretio, que a nobis et a vobis bene conplacuit, et de ipso pretio apud vos nicil remansi; ita ut de odie die et tempore ipsa terra de nostro iure abstersa et in vestro iure sit tradita atque confirmata» ${ }^{123}$. En otro documento inmediatamente posterior, se expresa la fórmula llamada a tener más éxito en el futuro: «Et si super est ereditas quod precium, dimitimus eum», reproducida prácticamente en todos los contratos de compraventa de los siglos XI y XII ${ }^{124}$. Un documento del Tumbo de So-

${ }^{121}$ Vid. FERNÁNDEZ ESPINAR, R., «La compraventa en el derecho medieval español», en Anuario de Historia del Derecho Español, XXV (1955), pp. 293-528, para quien no se halla en todo el derecho medieval tradicional referencias a la lesión enorme que es introducida oficialmente por el Fuero Real.

${ }^{122}$ Vid. BASTIER, J., «La vente dans les Asturies du $\mathrm{IX}^{\circ}$ au XII ${ }^{\circ}$ siècle: droit et économie», en Revue Historique de Droit Français et Étranger, vol. 57, 4 (octubrediciembre, 1979), pp. 569-609, quien habla de una cierta fijación en las fórmulas jurídicas que puede desesperar al investigador, pero que demuestra de forma clara y concluyente el carácter vivaz de los arcaísmos, la perennidad de ciertas reglas del derecho visigodo, desde los siglos VI (fecha del Código de Eurico) al XIV, en p. 583, con la consecuente ausencia de manifestaciones notorias de la penetración del derecho justinianeo.

${ }^{123}$ SERRANO, L., Cartulario de San Vicente de Oviedo (781-1200). Centro de Estudios Históricos, Madrid, 1929, doc. $n^{\circ}$. 95, pp. 103-104.

${ }^{124}$ Cartulario de San Vicente de Oviedo, doc. $\mathrm{n}^{\circ} .96, \mathrm{pp}$. 104-105. Otros ejemplos: doc. $n^{\circ} .100$, p. 108: «Et si superest ereditas quam premium, sit vobis dimissum»; doc. $n^{\circ} .102$, p. 110: «Et si superest hereditas quam premium, ad vos dimittimus eum»; doc. $\mathrm{n}^{\circ} .105, \mathrm{p}$. 113: «Et si superest ereditas quod precium, dimittimus eum», entre otros muchos ejemplos., que demuestran esa asimilación de la solución justinianea. Para el caso gallego, vid. FERNÁNDEZ DE VIANA Y VIEITES, J. I., La colección diplomática del monasterio de Santa María de Penamayor, p. 33, con las referencias documentales allí contenidas. 
brado, referido a un pleito entre los monjes del mencionado monasterio y unos tales Juan Petri y Pedro Petri, alude a que los «fratres dicebant quod emerant a predictis hominis suo iusto pretio supradictam hereditatem et homines dicebant quod non erat uendita sed supignorata», con alusiones a términos de indudable raíz romana como «cyrographarum» ${ }^{125}$.

En un contrato celebrado entre Ciz Ordoniz y su mujer Sancha con el presbítero Martín Iones, con fecha de 24 de abril de 1129, se vende una heredad en el valle de Sariego con pago en especie:

"Ideo placuit nobis et venit voluntas ut facimus nobis ad vobis kartam vendicionis de hereditate nostra propria, que habemus de habiorum vel de parentum nostrorum in territorio Asturiense in valle, que vocitant Sarego, villa pernominata Priudu, dabo tibi de mea hereditate divisa in illo montes in fontes in exitus indomitum vel pro domare vobis damus et in karta concedimos, pro que accepimus de vobis in precio vestire et in conduchu in parte et in cidra et in carne et in compannu precium placibilem, quod nobis et vobis bene complacuit, et de ipso precium non remasit pro dare; atamen si superest hereditas quam precium non dimittimus (...)»126.

La proximidad asturiana nos hace pensar en la similitud de las soluciones dadas en Galicia a los mismos problemas y la consecuente extensión de la cláusula referida a la rescisión por precio injusto en los términos ya examinados, aunque no hemos hallado en los diversos cartularios consultados remisiones expresas a esta posibilidad. Por ejemplo, en el caso del Tumbo de Sobrado, acaso por la ausencia de renovación en los propios cuadros monásticos y en su formación, prácticamente todas las escrituras de venta de bienes, desde el siglo $\mathrm{X}$ en adelante, contienen una cláusula de contenido similar en la que alu-

\footnotetext{
${ }^{125}$ Tumbos del monasterio de Sobrado de los Monjes. Edición de Pilar Loscertales de García de Valdeavellano. Archivo Histórico Nacional, Madrid, 1976. Tomo I, doc. $\mathrm{n}^{\circ}$. 456, pp. 410-411. Sin fecha, pero probablemente de los siglos XII-XIII.

${ }^{126}$ FERNÁNDEZ CONDE, F. J., TORRENTE FERNÁNDEZ, I., y DE LA NOVAL MENÉNDEZ, G., El monasterio de San Pelayo de Oviedo. Historia y Fuentes. Colección Diplomática (996-1325). Monasterio de San Pelayo, Oviedo, 1978. Tomo I, doc, $\mathrm{n}^{\circ}$. 8, pp. 32-33.
} 
de al placet dado por el comprador al precio, lo que puede darnos a entender de forma implícita, su conformidad con el mismo en el sentido expuesto por la legislación visigoda de precio convenido, pactado ${ }^{127}$. Lo mismo para el caso del monasterio de San Julián de Jubia en donde se recoge la misma cláusula ${ }^{128}$.

El cartulario del monasterio de San Pedro de Rocas nos permite ver la evolución a lo largo de tres siglos. Un primer documento recoge una venta hecha la monasterio de una heredad en Esgos, donde se dice «quia iam totum pretium nobis in pace persolvistis, sicut nobis et vobis bene complacuit» ${ }^{129}$ en el mejor estilo altomedieval, a pesar de corresponder a la segunda mitad del siglo XIII. En una venta de la primera mitad del siglo XIV, concretamente del año 1326, contiene la misma fórmula en romance: «ca outorgo e conosco que reçeby do prior sobre dito en nome do dito moesteiro por esto en prezo que aprouvo a min e a él» ${ }^{130}$. Otra venta de 1333 habla ya del «husso froyto das árvores que agora y están» y de la aceptación del precio «que reçebí ia de vos compridamente todo o preço que a min e a vos aprouvo de me por elo dardes (...) e outórgome delles por bem pagada» ${ }^{131}$. La referencia al «buen pago» o al hecho de sentirse bien pagado, entendemos, que alude implícitamente a la justicia

${ }^{127}$ Tumbos del Monasterio de Sobrado de los Monjes, ed. cit. Tomo I, doc. $\mathrm{n}^{\circ}$. 12, $\mathrm{p}$. 45. Año 945: «Et accepimus de uso in aderatum et firmum precium equa colore rosela et alium precium quod mihi bene complacuit»; doc. $n^{\circ}$. 22, pp. 54-55. Año 931: «Ipsa itaque portione integra uobis uendimus atque concedimos et accepimus de uso in aderato et definido precio uobe colore nigro iliaco placibile qui nobis bene complacuit et de ipso precio apud uso nichil remansit in debito, et quicquid uso de ipsa hereditate facere uolueritis (...)»; doc. $n^{\circ} .172$, p. 218. Año 1171: «Damus uobis et concedimos et accepimus de uobis precium quod nobis bene complacuit, et de ipso precio apud uso nichil remansit (...)»; doc. $n^{\circ} .226$, p. 262. Año 1193: «Uendo uobis pro precio cum suo robore uidelicet solidos decem Turonenses, quod utrisque partibus bene complacuit».

${ }^{128}$ La colección diplomática de San Martín de Jubia (977-1199). Edición de Santiago Montero Díaz. Tipografía El Eco Franciscano, Santiago, 1935, doc. nº. 10, pp. 63-64. Año 1087: «Et adeo accepimus de uobis precium per complacentia nostra (...) et quod nobis bene complacuit uso dedistis et nos accepimus et de pretio nichil remansit in debito"; doc. $\mathrm{n}^{\circ} .12$, p. 65. Año 1093: «et pretio mihi placuerit».

${ }^{129}$ El monasterio de San Pedro de Rocas y su colección documental. Edición de Emilio Duro Peña. Instituto de Estudios Orensanos Padre Feijoo, Orense, 1972, doc. n. 30, pp. 154-155. Año 1260.

${ }^{130}$ El monasterio de San Pedro de Rocas, doc. $n^{\circ} .62$, p. 175. Año 1326

${ }^{131}$ El monasterio de San Pedro de Rocas, doc. ${ }^{\circ}$. 68, p. 180. año 1333. 
del precio ${ }^{132}$. A finales de esa centuria, en el año 1371, la romanización de los contratos de venta era evidente: se habla ya de la «corporal posisón delo», pero se añade:

"Ca outorgo e connosco que reçebi de vos compridamente todo o preço que a min e a vos aprouvo de min por elo dardes, convén a saber, (...) do qual preço min fezestes pago en dineiros feitos e contados, do qual me outorgo por entergo e ben pagado, e renunçio sobrelo a a excepción de non numerata pecunia» ${ }^{133}$.

En este ámbito, pues, la penetración es más lenta, aunque se pueden hallar auténticos textos elaborados por especialistas en derecho romano. Podemos leer así en un contrato de venta del siglo XIV una presencia más profunda de cláusulas romanas:

«(...) Por preço nomeado que de vos reçebí, conbén a saber, çento e çincoenta e sete mrs de que me outorgo por ben pagado en presença deste notario e ts. adeante escriptas, os quaes dineiros e mrs son pasados a mina mao a des dineiros por maravedi, et renuncio a ley de mal enganno et a ley e eyxciçon de nomerata pecunia en que dis que o notario nes as ts. non viron contar os ditos dineiros nen fazer a dita paga et todas las outras boas raçoes et eyxençoes que contra esta bençon e contra parte della podese diser e alegar» ${ }^{134}$.

En algunos casos, se intenta superar los inconvenientes derivados del precio injusto o abusivo con el recurso a otra cláusula que salva la aplicación de las medidas sancionadoras: se acude a la ficción de donar el bien

${ }^{132}$ El monasterio de San Esteban de Ribas de Sil. Edición de Emilio Duro Peña. Instituto de Estudios Orensanos Padre Feijoo, Orense, 1977, doc. ${ }^{\circ}$. 50, p. 287. Año 1265: «E reçebí de vos preço IIII soldos que a min e a vos aplougo e de que soo bem pagada»; doc. $\mathrm{n}^{\circ}$. 52, pp. 288-289. Año 1273: «Que tod preço a min ben pagastes in paz por ella»; doc. $n^{\circ} .53$, p. 289. Año 1276: «Do qual prezo se outorgaron por ben pagados»; doc. $n^{\circ} .55$, p. 290. Año 1278: «E reçebemos de vos preço $C$ e XL e un soldo que a nos e a vos plougo e de que nos connoçemos que somos ben pagados»; doc. $n^{\circ} .84$, p. 317 . Año 1364: «Por preço nomeado que a min e a vos ben prougo, convén a saber, seteenta moravedís dos quaes moravedís me outorgo por ben pago»».

${ }^{133}$ El monasterio de San Pedro de Rocas, doc. $\mathrm{n}^{\circ}$. 111, p. 212. Año 1371.

${ }^{134}$ El monasterio de San Esteban de Ribas de Sil, doc. nº. 99, p. 332. Año 1391. 
en la cuantía excedida en función de ciertos comportamientos previos del que recibe el objeto ${ }^{135}$.

Con el tiempo, los notarios acentúan su dependencia del romanismo militante que se está imponiendo. Podemos leer en una venta del año 1422 que el vendedor otorga al comprador «de feyto et de dereyto et por ende todo jur señorio posison propiedade dereyto boz et abçon que eu ey et auer deuo», para añadir a continuación que se trasfiere «meto et apodero ena rrayal corporal posyson dela para quea ajades liuremente para sempre por jur de uosa propia herdade sen embargo de min et de miña uoz», para acabar con las correspondientes renuncias, una de las cuales alude a la del justo precio, como no podía ser de otra manera:

«rrenunço et parto de min et de mina voz a todo dereyto escrito et non escrito canonico ciuil comunal monicipal rrayal et esperitual et aeixeiço que falla en rrazon do engaño de mays ou de menos da meidade do justo preço et aley et dereyto que dyz que en termino de quatro años pode dizer et alegar o fazedor do contrauto que foy engañado da medade ou do mays ou do menos do justo preço et todas las outras leyes et dereytos que ami sobresto podesen aproveytar et a vos enpesçer» ${ }^{136}$.

\section{4.- La evolución del foro gallego}

Uno de los campos en los que mejor se puede apreciar el tránsito de la experiencia altomedieval a la etapa del Renacimiento jurídico es el de los derechos reales. Tanto el derecho de propiedad como la variada gama de instituciones tradicionalmente englobadas bajo la rúbrica de «contratos agrarios» sufren en el tránsito a la nueva época jurídica una mutación de su percepción. No hay un cambio en su naturaleza jurídica, ni una nueva formulación de sus aspectos esenciales, poderes o límites. La labor de los juristas boloñeses consistirá precisamente en un proceso de catalogación

${ }^{135}$ ROMANÍ MARTÍNEZ, M., Colección diplomática do mosteiro cisterciense de Sta. María de Oseira (1025-1310), ed. cit. Tomo II, doc. 1.362, p. 3. Año 1311: «Vendemos vol-la por duas moedas de VI moravedis (...) et se mays val damos vol-lo en doaçon por moy algo que nos feçestes»; doc. $n^{\circ}$. 1.373, p. 13. Año 1312: «Et si mays val damosvolo en doaçom por amor que nos fazestes».

${ }^{136}$ MARTÍNEZ SALAZAR, A., Documentos gallegos de los siglos XIII al XVI, ed. cit., doc. $n^{\circ} .63$, pp. 135-136.

«CUADERNOS DE ESTUDIOS GALLEGOS», Tomo XLVIII, Fascículo 114, Santiago 2001. 
o subsunción de las figuras más relevantes de la experiencia altomedieval conforme a los principios, categorías y conceptos típicos de las fuentes romanas. El resultado es una realidad que se aparta tanto del precedente romano como del precedente inmediato del Medievo: basta citar la doctrina del dominio útil y directo como un ejemplo claro de ese proceso de construcción, amparado en el derecho justinianeo, pero proyectado magistralmente sobre aquellas instituciones típicas del momento feudo-señorial en que se vivía. Un nuevo derecho, por tanto, aparece, resultado de la amalgama entre el caudal conceptual que aporta el elemento romano, el naturalismo que impregna las instituciones típicamente medievales y el esfuerzo de adaptación de los elementos anteriores al mundo profundamente señorial en el que vive la Europa del momento, creación ésta donde se muestra el genio de los juristas boloñeses en su vertiente teórica y práctica ${ }^{137}$.

El ejemplo que más conviene a Galicia sobre la cuestión es el del foro. Conforme a la idea que he defendido en mi tesis doctoral, en vías de publicación ${ }^{138}$, sobre la naturaleza jurídica de esta institución, deben rechazarse las posturas que veían en aquél una supervivencia de la antigua propiedad celta ${ }^{139} \mathrm{o}$ una institución típicamente medieval ${ }^{140}$.

${ }^{137}$ En este sentido expresado, son fundamentales las aportaciones de GROSSI, P., Locatio ad longum tempus. Locazione e rapporti reali di godimento nella problemática del diritto comune. Università di Macerata. Publicación della Facoltà di Giurisprudenza. Morano Editore, Pompei, 1963; Le situación reali nell'esperienza giuridica medievale. Corso di storia del diritto. Casa Editrice Dott. A. Milani, Papua, 1968; Il dominio e le cose: percezioni medievali e moderne dei diritti reali. Biblioteca per la Storia del Pensiero Giuridico Moderno, $\mathrm{n}^{\circ}$. 41. Giuffrè, Milán, 1992; La propiedad y las propiedades. Un análisis histórico. Editorial Civitas, Madrid, 1992; y El orden jurídico medieval. Marial Pons Ediciones Jurídicas y Sociales, S.A., Madrid, 1996.

${ }^{138}$ Vid. MARTÍNEZ MARTÍNEZ, F., Vias jurídicas para el aprovechamiento de los patrimonios señoriales. De la enfiteusis al foro. Los foros urbanos en la ciudad de Santiago de Compostela (Siglos XVI-XVIII). Tesis Doctoral inédita. Universidad de Santiago de Compostela, Santiago de Compostela, 2002. Tomo I, capítulos III y IV, sobre todo. Remito aquí al lector para cualquier duda que pueda derivarse del texto principal.

${ }^{139}$ Como propugnaba MARTÍNEZ MURGUÍA, M., Estudios sobre la propiedad territorial de Galicia. El foro: sus orígenes, su historia, sus condiciones. Librería de Bailly Bailliere, Madrid, 1882.

${ }^{140}$ Entre otros, PARDO BAZÁN, J., «Estudios sobre la propiedad en Galicia. Foros: su historia, sus ventajas, sus inconvenientes», en Revista de Galicia. Periódico de sus intereses materiales, morales é intelectuales, 1 (1 de junio de 1850), pp. 19-30; PLA Y 
El foro es una evolución -peculiar, eso sí- de la antigua enfiteusis romana y en su periplo vital deben señalarse dos momentos decisivos, marcados por el tránsito hacia la plenitud del Derecho Común. Hasta los siglos XII-XIII, el foro se inserta en la propia dinámica de los contratos agrarios medievales y en la propia dogmática (si es que se puede emplear esta expresión) del derecho altomedieval, con las notas que le son inherentes. Al esquema jurídico básico del foro, se le suman una serie de aditamentos, configurados esencialmente por gravámenes y prestaciones señoriales, que tienden a desaparecer a medida que la institución va evolucionando. En las centurias citadas, se produce, sin embargo, un proceso de subsunción del foro en el mundo conceptual romano: el foro es insertado en la dogmática justinianea y es calificado a todos los efectos como una auténtica enfiteusis, sin perjuicio de ciertas matizaciones o peculiaridades que van a servir para singularizarlo dentro del mundo de los censos ${ }^{141}$.

CANCELA, B., «De los foros y contratos enfitéuticos», en el volumen ARTIAGA, A. y BAZ VICENTE, M. X. (eds.), Propiedade da terra e reforma liberal. Biblioteca de Clásicos Agrarios Galegos. Volumen III. Xunta de Galicia-Caixa Ourense, Santiago de Compostela, 1997, pp. 123-152; su artículos publicados en la Revista Jurídica y Administrativa de Galicia: «Noción jurídica de la enfiteusis», 6 (1 de marzo de 1852), pp. 161-172; «El feudo», 8 ( 1 de abriil de 1852); y «El foro en la Edad Media», 10 (1 de mayo de 1852); PAZ NOVOA, J. M., Los foros de Galicia. Apuntas sobre la actual organización de la propiedad territorial en estas cuatro provincias y necesidad de su reforma. Imprenta de D. Francisco Paz, Orense, 1872; LEZÓN FERNÁNDEZ, M., El derecho consuetudinario de Galicia. Imprenta del Asilo de Huérfanos del S. C. de Jesús, Madrid, 1903. Acaso el más acérrimo defensor de esta postura fue VILLA-AMIL Y CASTRO, J., Origen de los foros en Galicia. Causas de su decadencia actual. Tipografía de Manuel G. Hernández, Madrid, 1883; y Los foros en la Edad Media. Estudio de la transformación que ha sufrido en Galicia la contratación para el aprovechamiento de las tierras. Establecimiento Tipográfico de los Sucesores de Rivadeneyra, Madrid, 1884. Recientemente, PORTELA SILVA, E. y PALLARES MÉNDEZ, M. C., «Los cotos como marco de los derechos feudales», en De Galicia en la Edad Media. Sociedad, espacio y poder. Xunta de Galicia, Santiago de Compostela, 1993, pp. 163-190.

${ }^{141}$ Opinión avalada por los más importantes tratadistas de la cuestión foral, como, por ejemplo, GIL VILLANUEVA, J., De los censos según la legislación geneal de España. Tipografía de José M. Paredes, Santiago de Compostela, 1880; SÁNCHEZ DE OCAÑA, R., Estudio crítico de las diversas especies de censos en la historia, en la legislación y en las costumbres. Imprenta y Litografía de los Huérfanos, Madrid, 1882; JOVÉ Y BRAVO, R., Los foros. Estudio histórico y doctrinal, bibliográfico y crítico de los foros, en Galicia y Asturias. Imprenta de la Revista de Legislación, Madrid, 1883; 
Teniendo necesariamente como punto de partida el predominio señorial en la Europa medieval, debemos poner de relieve cómo aquellos señoríos eran unidades económicas que tenían que ser explotadas en provecho de los respectivos titulares. En su seno aparecen singulares creaciones normativas, generadas por y para provecho directo de los intereses económicos de los propios señores. Admitida la persistencia del ordenamiento jurídico visigodo, según opinión ya indicada y comúnmente aceptada por la doctrina (sin entrar a valorar las influencias que hacen nacer la dispersión jurídica que caracteriza las primeras centurias medievales), no debe soslayarse el hecho indicativo de que esa persistencia en ningún momento, como ya hemos indicado, supuso la inalterabilidad del legado normativo gótico, ni una idéntica aplicación práctica del mismo en todos los territorios cristianos o donde habitasen una mayoritaria población cristiana, ni siquiera la aplicación íntegra de todas y cada una de sus normas. Incluso se puede afirmar, siguiendo a la mejor doctrina, que el mantenimiento del derecho visigodo no se realizó bajo los parámetros del propio sistema político que lo había generado, es decir, la vigencia de aquél se produjo no en consideración a su calidad de obra legislativa de un monarca, sino en su condición de ordenamiento profundamente enraízado en la colectividad, como derecho vivido y aceptado sin contradicción por las comunidades políticas, como derecho tradicional.

Pero el derecho visigodo necesitaba nuevas formulaciones, nuevas normas, nuevos creadores de las mismas. Aquí es donde comienza a cobrar un claro protagonismo el poder de los señores. Bajo la consideración de prestaciones señoriales o de contratos concertados entre aquellos y los cultivadores de sus tierras, se oculta toda una amplia gama de imposiciones unilaterales de los propios señores, revestidas de la consideración de derecho tradicional o consuetudinario. Es el origen del llamado derecho

LÓPEZ DE LAGO, R., «Memoria sobre foros y sociedad gallega, presentada á la Comisión de codificacion para la formación del nuevo Código civil», en Revista General de Legișlación y Jurisprudencia, tomo LXII (1883), pp. 448-489; BARROS PENA, J. A., Los foros en Galicia. Ensayo jurídico-social. Establecimiento Tipográfico de Alende, Santiago de Compostela, 1897; CASTRO BOLAÑO, J. M., Estudio jurídico sobre el foro considerado en su doble concepto de contrato y derecho real. Talleres Tipográficos de El Norte de Galicia, Lugo, 1902; LIS, M., Los foros en Galicia. Tipografía de la Viuda de J. A. Antúnez, Madrid, 1912; y PÉREZ PORTO, J., El derecho foral de Galicia. Imprenta y Litografía de L. Lorman, La Coruña, 1915. 
señorial, cuyo contenido estará orientado, sobre todo, a regular las relaciones de sujeción política y económica entre los poderosos y sus subordinados. El carácter de célula económica que presentan los dominios señoriales exige la correlativa organización para la obtención de los correspondientes recursos que permitiesen garantizar la autosubsistencia con una forma de explotación medianamente racional. Por ese motivo, se generalizan a nivel europeo y a nivel peninsular, una tradicional división de las tierras señoriales en dos grandes bloques: la reserva, trabajada directamente por el señor, y las tierras dependientes, divididas en unidades de producción de diferente nombre (manso es la expresión más extendida), entregadas a cultivadores libres empleando las más diversas fórmulas jurídicas. En relación a éstas, se produce la conjunción de dos factores: la influencia romana con la persistencia de las soluciones heredadas de Roma (enfiteusis, precario) y el nacimiento de nuevas modalidades de aprovechamiento nacidas de las propias necesidades medievales (la complantación, las cartas pueblas). Todos estos contratos agrarios, denominación formulada por el profesor Paolo Grossi, presentarían tres notas, a saber, su carácter mejoraticio, su larga duración y la concesión de un elenco amplio de facultades a los cultivadores, convertidos en propietarios fácticos.

De esa herencia romana procede la enfiteusis, base del foro, puesto que permitía realizar a la perfección los intereses de los señores y de los cultivadores. He ahí la razón de su gran extensión por toda la Península Ibérica, aunque con denominaciones variadas. En la existencia del foro, se pueden diferenciar, pues, dos grandes períodos que tienen como punto de inflexión el proceso de recepción del Derecho Común alrededor de los siglos XII y XIII. Durante los primeros siglos medievales, el foro aparece como un clásico contrato agrario con las notas arriba indicadas, a las que se van sumando una serie de aditamentos procedentes de la sola voluntad de los señores. A los elementos que servían para disciplinar las relaciones agrícolas se le van a añadir otra suerte de elementos metajurídicos: prestaciones señoriales típicas como hacerse vasallos del señor, la luctuosa, la abadía, el yantar, los guantes o entradas. Es un auténtico complejo señorial.

La introducción y el empleo del foro no tiene tampoco secretos: fue impulsado por los señoríos monásticos y eclesiásticos que repueblan Galicia, los cuales beben de las fuentes de explotación consagradas en la 
legislación justinianea de las Novelas (concretamente, las Novelas 7 y 120), dedicadas precisamente a los bienes de las iglesias. Sin embargo, esa enfiteusis justinianea, arranque del foro, no se transpone en su integridad. El foro no es pura y simplemente una enfiteusis, puesto que en el sistema jurídico del momento no se podía dar esa equiparación jurídica. Hereda algunos aspectos de la misma, recuerda vagamente a aquélla, recibe por medio de las costumbres canónicas algunos de sus rasgos, pero no se puede identificar totalmente. Se impone el naturalismo que caracteriza al derecho medieval.

Sin embargo, la recepción del Derecho Común cambia este planteamiento. El desarrollo de este proceso provocará un efecto que se puede calificar como clave en la historia del foro. Los estudiosos del Derecho Común, glosadores y comentaristas, procedieron a la reformulación de las instituciones medievales con arreglo a las categorías jurídicas existentes en el nuevo orden jurídico redescubierto. El foro no cambia, no se modifica su naturaleza jurídica. No se inventa una nueva naturaleza. Simplemente, el reciente clima jurídico que se respira fuerza a los juristas a aplicar las categorías que conocían (las del derecho romano y las del derecho canónico) a aquellas realidades jurídicas precedentes, en principio alejadas de esos mismos postulados teóricos. Se trataba de conseguir la armonización plena y perfecta entre las necesidades sociales, los elementos naturalistas del derecho medieval y los conceptos y categorías intelectuales del nuevo derecho recuperado. El foro se vacía en el molde de la enfiteusis eclesiástico-justinianea y con ello se equipara a la misma ${ }^{142}$. No hay, repito, un cambio en la institución. Hay un cambio en la perspectiva desde la cual se observa, califica y estudia la misma. Ello obedeció a una suma de intereses complejos, dentro de los cuales debe destacarse un nada despreciable intento de obtener la seguridad jurídica que el etéreo derecho consuetudinario anterior no podía proporcionar. De la mencionada seguridad jurídica derivaría una seguridad económica en la percepción de las rentas y un instrumento de control social de indudable trascendencia. Se abandonaron los reductos consuetudinarios y se depositó el foro

${ }^{142}$ De todos modos, la equiparación no es total y absoluta. Como he demostrado en mi tesis, hay, al menos, tres diferencias básicas entre la enfiteusis y el foro que simplemente apunto: la duración, el régimen de la destrucción de la cosa, y el tratamiento de las mejoras y de los perfectos realizados en los bienes forales. 
en brazos de un derecho de tipo legal y racional, totalmente fijado por escrito (el derecho de las Partidas y de los textos romanos). La coincidencia de la mayor parte de las cláusulas de los contratos forales con los preceptos recogidos en las Partidas deja constancia fehaciente de esta equiparación que alcanzará su culminación en la época moderna. Veamos un comparación entre tres textos, relacionados entre sí, para ver el paralelismo e influencia recíprocas que se puede respirar: la versión castellana de $L o$ Codi $i^{143}$, un contrato foral del año 1213, procedente del monasterio de Oseira ${ }^{144}$, y textos de las Partidas ${ }^{145}$. El primer texto, datado en el siglo XII, fue una de los que más decididamente fomentó el conocimiento del derecho romano en la Península y en él se inspiraron las Partidas en sede de enfiteusis ${ }^{146}$. Se trata, como se sabe, de un resumen del Código de Justiniano. El foro gallego, anterior al texto alfonsino, toma elementos de Lo Codi, por lo que no es extraño suponer que se tuviese conocimiento de aquella obra en la región gallega. Finalmente, los redactores de las Partidas tomarán aquella obra como uno de los elementos básicos para la composición del código alfonsino pues les permitía disponer del texto justinianeo en una forma abreviada. En concreto, los textos transcritos se refieren a los derechos de tanteo a favor del dominio directo y a la prohibición de transmitir a «persona prohibida» el censo constituido. En ellos, las semejanzas son incuestionables, sin perjuicio de las diferencias de estilo, fruto de la diversa formación de sus autores, más elevada en Partidas y Código, más pragmática, directa en el caso del contrato:

\footnotetext{
${ }^{143}$ Citamos por la siguiente edición: Lo Codi en castellano, según los manuscritos 6.416 y 10.816 de la Biblioteca Nacional. Edición y estudio preliminar de Juan Antonio Arias Bonet. Universidad Complutense. Facultad de Derecho, Madrid, 1984, pp. 222-225.

${ }^{144}$ ROMANÍ MARTÍNEZ, M., Colección diplomática do mosteiro cisterciense de Sta. María de Oseira (1025-1310), ed. cit. Tomo I, doc. nº 151, pp. 155-156.

${ }^{145}$ Citamos por la edición del Boletín Oficial del Estado, Madrid, 1974. Tomo III, f. 52.

${ }^{146}$ De acuerdo con ALONSO MARTÍN, M. L., «Los orígenes de la enfiteusis en Castilla: notas para su estudio», en Actas del I Congreso de Historia de Palencia. Diputación Provincial de Palencia, Palencia, 1987. Tomo III, pp. 293-308.
} 
Lo Codi

4, 72, 8 .

Aquel ome que tiene alguna cosa por renda assi como es dicho de suso si él quiere vender o donar en alguna guisa o agenar aquel derecho que él a en la cosa bien lo puede fazer segund en el pleyto que fizo con el señor de la cosa quando él la tomó, si el pleyto fue escripto. Mas si el pleyto non fue escripto o si fue escripto e non paresçe el escripto aquel que tiene la cosa debe yr al señor de la cosa e deve dezir qu'el quiere vender el derecho que él y a e deve'l dezir el presçio que ome le quier dar. Et si el señor le quiere dar otro tanto como otro, dévegela dexar en antes que a otro ome. Mas si el señor non lo quiere comprar o quiere e non quiere dar otro tanto como otro él deve estar fasta dos meses que non venda aquel derecho e a cabo de dos meses develo dezir otra vegada al señor d'aquel derecho e si el señor no'l quiere dar a tanto como otro ome estonçe puede vender a quien quissiere la cosa pues que seran pasados los dos meses aunque no quiera el señor de la cosa, si non sea tal persona que sea vedado a ella.

\section{Contrato de Foro}

Partidas

Et non debemus eam dar in elemosinam alicui loco, vel persona nisi monasterio Ursariae, nec debemus eam vendere nec impignorare, nec aliquo modo dare militi nec clerico, nec alicui viro religioso nec aliqui ordini;

Sed si vendere voluerimus, prius debemus dicere abbatis et fratribus Ursariae et se ipsi voluerint pro ea dare iustum pretium eis debemus dare; sin autem debemus eam vendere vel dare rustico vel colono qui totum persolvere teneatur debitum predicto monasterio, sicut nos tenebamus

\section{5, 8, 29}

Enagenar e vender puede la cosa aquel que la rescibio a censo. Pero ante que la venda deue lo fazer saber al Señor como la quiere vender, e quanto es los quel dan por ella. E si el Señor le quisiere dar tanto por ella, como el otro estonce, la deue vender ante a el que a otro. Mas si el Señor dixesse que le non queria dar tanto, o lo callasse fasta dos meses que le non dixesse si lo quiere fazer, o non, dende adelante, puede la vender aquien quisiere e non le puede embargar aquel que gela dio a censo que lo non faga. Pero deue la vender atal ome de quien pueda el Señor auer el censo, tan ligero como del mismo. 
Merecen citarse para concluir esta consideración sobre el foro aquellas hermosas palabras que formulara en su día José Reino Caamaño reflexionando sobre su periplo histórico:

"Hijo de la costumbre, fue llevado por los juristas al templo de la ley, bautizándolo los Tribunales en la pila del censo enfitéutico, derramando sobre él principios y doctrinas en los Códigos establecidas para la enfiteusis» ${ }^{147}$.

\section{5.- Una sentencia clarificadora}

Acaso el documento que marca de una forma más concluyente ese proceso lento y continuado de implantación de los esquemas romanos en detrimento del derecho de corte popular y privilegiado que hasta entonces había regido el territorio gallego, se puede observar en una sentencia pronunciada por Alfonso X el Sabio en Sevilla a los efectos poner fin a uno de los múltiples conflictos que protagonizaron la Iglesia de Santiago y el concejo de la misma ciudad en sus luchas por el poder. Resultado paradójico el que contiene el pronunciamiento por proceder del monarca gracias al cual el Derecho Común tomó carta de naturaleza en el reino castellano-leonés. Pero también es cierto que nos encontramos todavía en los inicios del reinado alfonsino y que muchos de sus proyectos políticos y jurídicos no habían adquirido por entonces la consistencia y la madurez que harían entrar al mismo monarca en nuestra Historia jurídica. El documento a que nos estamos refiriendo pone sobre la mesa la existencia de una inserción generalizada en Galicia del derecho romano y del derecho canónico, a lo cual se van a oponer aquellos estamentos que se entendían lesionados o perjudicados por el contenido de las nuevas normas. La presencia de eclesiásticos entre los jueces de la ciudad explica en buena medida la orientación jurídica de las decisiones adoptadas y la posterior intervención regia ${ }^{148}$.

${ }^{147}$ Cfr. Informe de la Excelentísima Comisión Provincia de La Coruña redactada por el vocal ponente Don José Reino Caamaño acerca del Proyecto de Apéndice al Código Civil aprobado por la Comisión especial de Derecho Foral de Galicia. Litografía e Imprenta Roel, La Coruña, 1916, pp. 11 y 13.

${ }^{148}$ Cfr. PÉREZ RODRÍGUEZ, F. J., La Iglesia de Santiago de Compostela en la Edad Media, pp. 71 ss. 
La sentencia aparece fechada el día 8 de septiembre del año 1253 y es dada en la ciudad de Sevilla. Se dirige al arzobispo compostelano Juan Arias. Han intervenido, de acuerdo con los datos que proporciona el encabezamiento, el maestro Fernando y Pedro Martiz, ambos clérigos, en representación del prelado, y Arias Yáñez, Vidal Eanes y Jacobo Eanes, como personeros del concejo de Santiago ${ }^{149}$. Independientemente de otras cuestiones que se abordan en el largo pleito, dos son los pronunciamientos especialmente relevantes y que nos informan del avance imparable del Derecho Común.

Primeramente, la cuestión $\mathrm{n}^{\circ}$. 2 lleva por rúbrica «In quibus causis et qualiter clerici debent esse aduocati». Se refiere a un primer argumento del concejo según el cual los clérigos actuaban como abogados y en dichas intervenciones obviaban el derecho tradicional del reino y el privilegiado de la ciudad, invocando normas del derecho romano. Se muestra, por tanto, un primer camino de penetración del derecho romano derivado de la actividad consultiva y de asesoramiento que estos clérigos desempeñaban, clérigos que, evidentemente, se habían educado en los textos romanos y canónicos. Alfonso X ordena finalmente la aplicación obligatoria del derecho tradicional, conformado por el Fuero Juzgo y por los usos y costumbres locales, y prohíbe el ejercicio de la abogacía a los clérigos:

"Otrossi, querelaron los personeros sobredichos del conceio e Santiago que en la Eglesia de Santiago ha bonos clerigos et bien leterados, et quando los uecinos della uilla ham pleytos ante los juizes clérigos, entram los clerigos por avogados et demoran ó derecho por tres anos o por quatro; de guisa que non poden auer derecho con ellos; et por sus sotellezas et por leyes Romanas, que son contra el liuro de leon et

${ }^{149}$ Cfr. LÓPEZ FERREIRO, A., Fueros municipales de Santiago y de su Tierra. Edición facsimilar. Ediciones Castilla, S.A., Madrid, 1975, p. 251: «Don Alfonso, por la gracia de Dios, Rey de castella, de tolledo, de leon, de Galliza, de Seuilla, de cordoua, de murça, de Jahen, á uso Johan arias, por la gracia de dios arçobispo de Santiago, salud, assy como á aquél que amo et en que fio. Sepades que meestre fernando uosso canonigo, et Pero martiz, su clérigo, cun uuestra carta de pesonaría et Aras perez poquitino et Vidal eans et Jacob eans pesoneros del Conceyo de Santiago cun su carta de pesonería uenieron ante mí (...)». 
contra sus usos et sus custumbres, et fazen perder al Conceyo sus derechos. Resposso maestre fernando uuestro personero sobredicho, que lo usaron en tiempo del Rey don fernando de anos a suso.

A esto tiue yo por bien que ninguno clérigo non touiesse uoz sobre cosa leygal contra lego; et la uoz que touiere non la tengam por leyes rromanas, nen por decretos nen por decretales, fuera por el fuero et por el derecho della tierra» ${ }^{150}$.

Pero la referencia expresa a esta cuestión no se detiene en esta sede. El primer problema, parece ser, el que suscitan los abogados eclesiásticos que aplican y defienden la aplicación del Derecho Común en toda clase de pleitos, retardando su solución y perjudicando de forma continuada los intereses del concejo. La complejidad del litigio se extiende asimismo a los cargos judiciales, copados, como no podía ser de otra forma, por miembros de la carrera eclesiástica, cercanos al arzobispo como señor que era de la ciudad. La cuestión $\mathrm{n}^{\circ}$. 10 se refiere ya expresamente a la prohibición de que los jueces juzguen por las leyes romanas y por las canónicas, sino que han de aplicar en todo caso el derecho del reino (el Liber) y el derecho especial de la ciudad. La propia rúbrica de la cuestión es toda una declaración de intenciones: «Quod judices non judicent per leges romanas et decreta, set per librum legionensem et per bonas consuetudines». La discusión se ha centrado en la aplicación en primera instancia del Derecho Común y en el rechazo a las apelaciones que a las mismas se efectúan. El argumento que el maestre Fernando esgrime se ampara en la tradicional actuación en otro sentido de los jueces compostelanos, desde la época de Fernando III y aún de Alfonso IX de León, dice, se viene efectuando la aplicación del derecho en el sentido que ahora demanda el concejo. Alfonso X reitera su anterior decisión: ha de aplicar en primer lugar el derecho propio de la ciudad y, en su defecto, el Libro de León, sin acudir en ningún caso a ordenamientos ajenos. Ello, eso sí, hasta que el rey determine con exactitud el contenido de los usos y costumbres de la ciudad.

${ }^{150}$ Cfr. LÓPEZ FERREIRO, A., Fueros municipales de Santiago y de su Tierra, ed. cit., p. 252. 
"Otrosy, querelaronse os pesoneros sobredichos del conceyo de santiago que los juizes non quieren judgar segund uso et custunbre de su uila, et judgan por sus leyes romanas; et pero (aunque) sobreste agrauamiento appellan pora ante mi, non les quieren recebir la appellacion.- Resposo maestre Fernando, uuestro pesonero sobredicho, et dixo, que non judgan seno como judgaron en tiempo del Rey don Alfonso et del Rey don fernando por fuero de leon et por custunbres derechas et por razones guisadas et por el libro judgo. De las appellaciones resposo como de suso es dicho.

A esto tengo yo por derecho que judgen por los sus usos et por los custunbres que usaron et que ouieron en tenpo del Rey don Alfonso myo auolo et de myo padre sen leyes de Roma et sen derecho et sen decretales; et ho falieren los custumbres et los usos, que judgen por lo libro de judgo. Et esto mando yo que sea assy fasta que yo sapa los usos et los custumbres et mande como sea» ${ }^{151}$.

Una decisión que vagamente recuerda a la que adoptó Jaime I para Cataluña dos años antes y que marcó un punto de inflexión en las relaciones entre los derechos tradicionales de los reinos y el nuevo Derecho Común. Pero el ascenso de este último era ya imparable como bien se pudo demostrar en las siguientes centurias.

Hemos intentado, pues, con estas breves y modestas líneas trazar un panorama lo más acertado posible que permita comprender cómo era la vida jurídica de Galicia en los años centrales de la Edad Media, con el objeto de examinar la llegada imparable del nuevo Derecho Común. Repetimos que nuestra finalidad era describir brevemente las causas, los efectos y las primeras manifestaciones de este peculiar fenómeno. En cuanto a las primeras, nos hemos centrado en el aspecto intelectual: la educación clerical, la presencia de escuelas catedralicias, las importantes bibliotecas de los centros religiosos, son los factores que crean el caldo de cultivo para que aflorase la nueva civilización jurídica del Derecho Común, auspiciada por el papel incuestionable del Camino de Santiago

${ }^{151}$ Cfr. LÓPEZ FERREIRO. A., Fueros municipales de Santiago y de su Tierra, ed. cit., p. 256. Esta sentencia y otra de 1261, han sido estudiadas por BERMEJO CABRERO, J.L., En torno a la aplicación de los Partidos» en «Hispania». Revista española de historia, XXX, 114 (1970), pp. 169-177. 
como vía de intercambios. En cuanto a los efectos, hemos manejado un elenco amplio de documentos desde el siglo $\mathrm{X}$ hasta el siglo XV, en los cuales se ha podido contemplar el paulatino proceso de inserción del derecho romano en la práctica usual a través de varias instituciones como las renuncias, las declaraciones de herederos, codicilos o el foro, para concluir en esa ejemplar sentencia de Alfonso X que demuestra el conflicto subyacente en toda esta dinámica entre el derecho tradicional propio y el Derecho Común. Recuperando aquellas preguntas que nos formulábamos al comenzar este estudio, debemos concluir que en Galicia sí se dio de forma coetánea al resto de los territorios peninsulares (en especial, los castellano-leoneses por motivos obvios) un primer proceso de penetración del Derecho Común que más adelante acabó deviniendo en una plena recepción. Los siglos XII y XIII marcan también para Galicia el camino hacia ese nuevo sistema jurídico traído de Italia y extendido a toda Europa. El viejo reino gallego no fue una excepción a esta tendencia desarrollada de manera plena, aunque el ritmo fue diverso. Las primeras manifestaciones de esa penetración, como se ha podido observar en la documentación manejada, se dan alrededor del siglo XII, de manera similar a lo que acontecía en los territorios peninsulares más avanzados como Cataluña, pero la consolidación y empleo usual de fórmulas romanas no cristaliza-hasta el siglo XIV. Desde ese momento, el proceso ya no sufriría ninguna interrupción y en las centurias siguientes se asisitirá al ascenso del Derecho Común, auspiciado por la «nacionalización» del mismo que se produce a través de las Partidas de Alfonso X el Sabio, las cuales constituían el derecho oficial del reino desde el año 1348, aunque ya con anterioridad habían venido siendo aplicadas por los tribunales y jueces del rey. Con ellas y a través de una interpretación auspiciada por los juristas castellanos más relevantes, se dio pasó al triunfo del Ius Commune, al menos hasta la llegada de los nuevos aires de renovación jurídica que trajo consigo el siglo XVIII.

«CUADERNOS DE ESTUDIOS GALLEGOS», Tomo XLVIII, Fascículo 114, Santiago 2001. 